\section{Ticari Küreselleşme, Ticari Açıklık ve Bölüşüm Olgusunun Gelir Eşitsizliği Üzerinden Değerlendirilmesi: OECD Ülkeleri Açısından Bir İnceleme}

\author{
Onur Ozdemir ${ }^{\mathrm{a}}$, Emrah Dogan
}

\begin{abstract}
Öz: Bu çalışma ticari küreselleşme ve ticari açıklık değişkenlerinin gelir eşitsizliği üzerindeki etkisini 1980-2016 arası dönem için OECD ülkeleri çerçevesinde incelemektedir. Temel analiz bağlamında elde edilen ampirik bulgular belirtilen dönem içerisinde kullanılan ticaret değişkenlerinin gelir eşitsizliğini artırdığını göstermektedir. Daha spesifik düzeyde fiyat değişimlerinden arındırılarak oluşturulan reel ticari açıklık değişkeninin de modellemelere dahil edilmesi sonucu gelir eşitsizliği ile aralarındaki ilişkinin negatif ve istatistiksel olarak yüksek oranda anlamlı çıktığı görülmektedir. Temel analiz sonuçlarını destekleyici nitelikte ek açıklayıcı değişkenlerin dahil edildiği sağlamlık testi analizlerinde de hem ticari açıklık hem de ticari küreselleşme değişkenlerinin gelir eşitsizliği üzerinde olumsuz etkisi bulunmaktadır. Çalışmada elde edilen bulguların ardındaki iktisadi mantık ise emek piyasasında meydana gelen negatif yönlü değişimlerin ele alınan dönemdeki sosyoekonomik sorunların temel nedenlerinden biri olduğu şeklinde değerlendirilmesi gerektiğidir. Diğer bir deyişle, ele alınan süreç içerisinde emek kesiminin pazarlık gücündeki düşüşsermaye kesiminin ulusal gelirden elde ettiği payı artırarak hanehalkı düzeyinde gelir eşitsizliğini ileri boyuta taşımaktadır.
\end{abstract}

\section{The Assessment of Trade Globalization, Trade Openness, and Distribution Through Income Inequality: An Examination in Terms of OECD Countries}

\begin{abstract}
This study examines the effects of trade globalization and trade openness on income inequality within the framework of OECD countries for the period 1980-2016. The empirical findings acquired in the context of baseline analysis show that both trade variables increase income inequality within the specified period. At a more specific level, the real trade openness variable, which is formed by adjusting from the price changes, is also included into the models in which its relationship with the income inequality is negative and highly statistically significant. In the robustness test analyses that include additional explanatory variables supporting the baseline results, both trade openness and trade globalization variables have negative effects on income inequality. The economic logic behind the findings of the study is that the negative changes in the labor market should be considered as the main cause of the negativities behind the basic variables used in the analysis. In other words, the decrease in the bargaining power of labor increases the income inequality at the household level by increasing the share of capital accruing from the national income.
\end{abstract}

Anahtar Sözcükler: Gelir Eşitsizliği, Ticari Küreselleşme, Ticari Açıkık, Bölüşüm, Pazarlık Gücü

JEL: D33, F4, F60

$\begin{array}{ll}\text { Geliş } & : \text { 14 Aralık } 2020 \\ \text { Düzeltme } & : 01 \text { Şubat 2021 } \\ \text { Kabul } & : 03 \text { Mart 2021 } \\ & \\ \text { Tür } & \text { : Araştırma }\end{array}$

Keywords: Income Inequality, Trade Globalization, Trade Openness, Distribution, Bargaining Power

JEL: D33, F4, F60

$\begin{array}{ll}\text { Received } & : 14 \text { December } 2020 \\ \text { Revised } & : 01 \text { February } 2021 \\ \text { Accepted } & : 03 \text { March } 2021\end{array}$

Type : Research

a Asst. Prof., PhD., Istanbul Gelisim University, Faculty of Economics, Administrative and Social Sciences, Department of International Trade and Finance (English), Istanbul, Turkiye, onozdemir@gelisim.edu.tr (ORCID ID: 0000-0002-3804-0062)

b Asst. Prof., PhD., Istanbul Gelisim University, Faculty of Economics, Administrative and Social Sciences, Department of International Trade and Finance, Istanbul, Turkiye, emdogan@gelisim.edu.tr (ORCID ID: 0000-0001-9870-5719) 


\section{Giriş}

Iktisadi olguların bir bütün içerisinde incelenmesi ve farklı disiplinlerle etkileşimi, yapılan çalışmaların sınırlarının belirlenmesi açısından önem arz eden konuların başında gelmektedir. Mevcut her olgu teorik bütünselliğin korunması açısından derinlemesine incelenmeyi gerektirmekte ve içsel bileşenlerinin öznelliği bakımından analize ihtiyaç duymaktadır. Bu durumun en önemli avantajı, birbirinden ayrı olguların soyutlama düzeyinde ortak parçalarının ortaya çıkarılması ve böylece disiplinler arası farklı konuların ortak bir zeminde buluşabilmesinin ardında yatan faktörlerin belirlenebilmesidir. Ayrıca farklı olgular etrafında oluşan karmaşık süreçlerin ve içsel bağıntıların daha iyi kavranabilmesini sağlamaktadır. Tüm disiplinler için geçerliliğe sahip bu olguların daha spesifik alanlardaki yansımaları ise bütünlüğe karşıt sonuçların ortaya çıkmasına neden olarak daha titiz araştırmaya ihtiyaç duyulmasını gerektirebilir. Bu çerçevede, mevcut çalışma iktisadi alandaki bu karşıtlıkların özellikle geçerliğini koruduğu ve farklı değişkenlere bağlı olarak dönüşüme uğradığı ticari açıklık ve ticari küreselleşme ile gelir dağıımı arasındaki ilişkiyi araştırmaktadır. Bu ilişkinin ele alınmasının ardındaki temel motivasyon, özellikle gelişmiş ve gelişmekte olan ülkeler bazında küreselleşmenin finans ayağı ile birlikte diğer önemli ayağını oluşturan ticaret hesabının bölüşüm üzerindeki etkisinin kriz sonrasında tartışmaya açılması ve geleneksel yaklaşımların aksine gelir dağılımında emek kesimi aleyhine olumsuz yönünün ağır bastığının ampirik bağlamda kanıtlanmaya çalışıımasıdır.

Çalışmanın içeriği küreselleşme ile bağlantısı açısından ticaret ve bölüşüm arasındaki ilişkinin varlığını analiz etme amacında temellenmektedir. Buradaki asıl sorun, ticaret ve bölüşüm arasındaki ilişkinin belirleyicileridir. Ayrıca ticareti etkileyen faktörler kadar bölüşümün içyapısındaki zaman boyutlu kırılmalar, mevcut ilişkinin dinamiklerini etkilemesi nedeniyle incelenecek diğer bir alanı oluşturmaktadır. Bu çerçevede, bölüşümün zaman içindeki değişiminin nasıl bir seyir izlediğinin ortaya çıkarılması ticaret ile bağıntısını anlamak adına gerekli politik ve ekonomik araçları okuyucuya sağlayacaktır. Ancak bu araçların ortaya çıkartılması bölüşümün metodolojik düzeyde farklı ölçüm yöntemlerini içermesi ve iktisadi okulların bölüşüm konusundaki görüş farklılıkları nedeniyle kolay bir sürece sahip değildir. Bu noktada farklı disiplinlerin veya belirli bir disiplin açısından bölüşümün nasıl tanımlandığından ziyade, daha soyut düzeyde nasıl sınıflandırılacağı bölüşüm-ticaret bağıntısının ortaya çıkarılması açısından daha ince noktaların görülmesini sağlayacak ve bütünselliğin oluşturulmasında atılacak yöntemsel adımların bir arada ele alınmasını beraberinde getirecektir.

Bu açıdan bakıldığında gelir bölüşümü mevcut bir olgu olarak iki ana kategoride incelenebilir: (i) kişisel gelir dağılımı ve (ii) fonksiyonel gelir dağılımı. Kişisel gelir dağılımı yaklaşımı yöntemsel olarak daha sınırlı bir içeriğe sahiptir. Temelde toplam ulusal gelirin bireyler, hanehalkları veya belirli gruplar arasındaki dağılımını tanımlar. Kişisel gelir dağılımının bileşenlerini doğru bir şekilde analiz etmesi açısından kullanılan veriler güvenilir olarak nitelendirilse de bireyleri homojen birimler olarak ele alması, aralarındaki sosyo-politik ve/veya kültürel farklılıkları hesaba katmaması ve ekonomik eşitsizliklerin zaman içerisindeki değişimlerini açıklamada sorunlu noktaları dışlaması nedeniyle iktisadi olguları açıklayıcı rollerini kaybetmektedir. Fonksiyonel gelir dağııımı yaklaşımı ise toplam ulusal geliri ortaya çıkaran üretim faktörleri arasındaki bölüşümü incelemektedir. Bu çerçevede sınıfsal bir boyuta sahip olan yaklaşım, üretim ve dağıtım anlarında ortaya çıkan sorunları ele alarak ekonomik eşitsizliklerin analizi açısından daha bütüncül ve detaylı bir yapı ortaya çıkarmaktadır.

Makale içerisinde bölüşümün analizi açısından kullanılacak değişken Gini katsayısıdır. Bu değişkenin kullanımasının temel nedeni, hanehalkı düzeyinde yaşanan gelir bölüşümüne ait dinamiklerin açıklanabilmesinin yolunu açması ve sosyo-iktisadi açıdan ortaya çıkabilecek sorunların analizine olanak sağlamasıdır. Ancak, küreselleşme sürecinde emek ve sermaye gelirlerinin zaman içerisinde ortaya çıkan farklılıkları, gelir bazlı çalışmaların cevaplaması gereken soruların başında bulunması açısından güncelliğini sürdüren bir detay olarak karşılarında durmaktadır. Her ne kadar gelir dağııımı açısından yöntemsel temelde farklılık arz etseler de hem ana akım/ortodoks perspektif hem de heterodoks perspektif toplam gelirin bölüşümünün çok çeşitli unsurlara sahip olduğu konusunda hem fikirdirler. Özellikle Dünhaupt (2017)'un belirttiği gibi, analitik ve teorik açıdan birçok çalışma bölüşüm olgusunun güncelliğini korumasında ortak bir zeminde buluşmaktadır. 
Ticari açıklığın ve ticari küreselleşmenin bölüşüm üzerindeki etkileri iki farklı perspektiften incelenebilir. Bunlardan ilki ana akım paradigmanın bağlı olduğu söylemlerdir. Ana akım yaklaşım gelir dağılımında yaşanan sorunların baş aktörlerinden biri olarak ticari rejimin regülasyonlara bağlı kılınmasını göstermekte, dolayısıyla toplumsal sınıfların emek mobilitesi açısından belirli sınırlar içerisine hapsolduğunu belirtmektedir. Daha eşitlikçi bir bölüşüm mekanizmasının ortaya çıkmasının ön koşulu olarak ticaret rejimine bağlı kanalların belirli oranlarda dışa açık olması gerektiği vurgulanmaktadır. Bu nedenle, mal ve hizmet ticaretini ve emek akışkanlığını önleyecek her türlü iktisadi ve politik müdahalenin gelir dağııımında karşlığını bulacağını öne sürmektedir. Diğer taraftan, karşıt görüşler kendi içinde belli bir bütünlüğe sahip olmasa da emek piyasası üzerinden yapılan çalışmalar sınıfsal açıdan ticari açıklık ve ticari küreselleşme olgularını gelir dağılımı ile ilişkilendirerek bölüşüme farklı bir bakış açısı kazandırmaktadır. Bu görüşlerin ardındaki teorik altyapı emek-sermaye arasındaki iktisadi güç ilişkilerine bağlı olarak şekillenmektedir. Bu iktisadi güç ilişkileri büyük oranda bir sınıfın kaybı diğer bir sınıfın ise kazancı ile sonuçlanmaktadır. Örneğin, Grafik 1 OECD ülkeleri için toplam ulusal gelirden emeğin aldığı payı göstermektedir. 1980-2017 yılları arasında sert bir düşüş gösteren emek payının kaybı sermaye payının kazancı olarak rahatlıkla okunabilir.

Grafik 1. Emek Payının Zaman İçindeki Eğilimi (1980-2017)

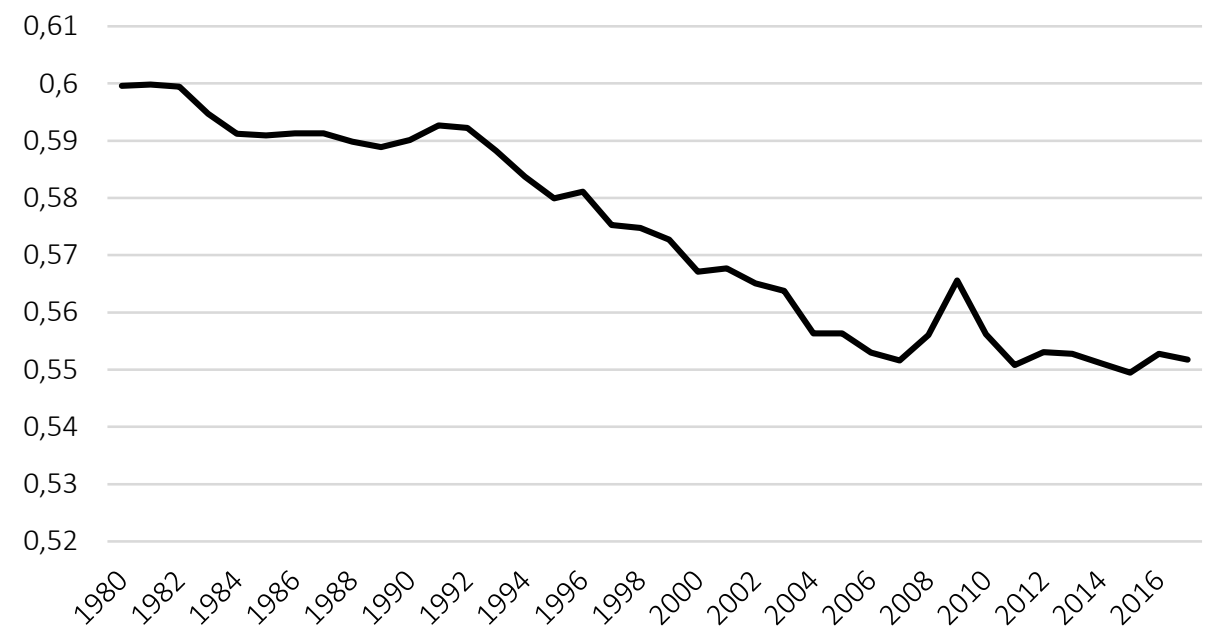

Kaynak: Penn World Tables 9.1.

Görüldüğü üzere, OECD ülkelerinde emeğin toplam ulusal gelirden elde ettiği pay azalmaktadır. Bunun ardındaki nedenlerin ülke içi ve ülkeler arası durumlara göre değişmekte olduğunu belirtmek gereklidir. Ayrıca her ülkenin kendine özgü sosyo-ekonomik, politik ve kültürel farklarını ele alarak daha derin bir analize ihtiyaç duyulmaktadır. Ancak makale çerçevesinde bu olguları temelden etkileyen ve özellikle 1980 sonrası küresel bir nitelik kazanan iktisadi ilişkilerin dinamiğini oluşturan ticari açıklık ve ticari küreselleşme başlıkları incelenerek bölüşüm üzerindeki etkileri araştırılacaktır. 1980-2016 arası dönem çerçevesinde OECD ülkeleri için incelenecek olan bu ilişkinin ardındaki temel motivasyon, hanehalkı düzeyinde ana akım küreselleşme yanlısı söylem ve argümanların farklı sosyo-iktisadi ve politik faktörlere bağlı olarak geçersiz bir yapıya sahip olduğunu göstermektir. Diğer bir deyişle, küreselleşmenin en önemli ayaklarından ticari serbestleşme gerekliliğinin bölüşüm açısından etkilerinin bekleneni karşılamaktan çok uzak olduğu görülmektedir. Bunun en temel nedeni sınıfsal düzeyde sermayenin ticari düzeyde elde ettiği kazanımları ve dolayısıyla iktisadi gücü elinde bulundurarak emek karşısında pazarlık gücünü artırmasıdır.

Özellikle sosyal hak kayıpları ve emek piyasasındaki ayrışmalar sonucu pazarlık gücünde emek aleyhine meydana gelen gelişmeler uzun dönemli iktisadi kayıpların ortaya çıkmasına neden olmaktadır. Buradan yola çıkarak çok farklı değişkenlerin mevcut sürecin ardındaki potansiyel faktörler olarak geleneksel göstergelerin yerini aldığı görülmektedir. Bu çalışmada ülkelerin ticaret hesaplarında uygulanan dışa açıkık ve küreselleşme politikalarının bölüşüm üzerindeki güç ilişkilerine bağlı olarak toplam ulusal gelirin yüzdelik diliminin alt gruplarını oluşturan hanehalkı aleyhine bir sonuç yarattığı vurgulanmak istenmektedir. Karşıt 
literatürün bu iki değişken arasındaki ilişkiyi yüzeysel olarak ele alması ve bu negatif ilişkinin nedenlerini büyük oranda dışlaması dolayısıyla bu makale, ticaret-bölüşüm bağıntısının asıl belirleyeni olarak sınıfsal düzeyde güç ilişkilerinin varlığını vurgulamaktır. Diğer bir deyişle, daha liberal ticari rejimlerin ortaya çıkması farklı kanallardan emek ve sermaye arasındaki ve özellikle emek piyasasındaki ilişkileri çalışanlar aleyhine olumsuz olarak etkileyerek ulusal gelirden alınan payın bölüşümünde potansiyel negatif faktörlerin şiddetini artırmakta ve böylece gelir eşitsizliğini hem yerel hem de uluslararası düzeyde artırmaktadır. Grafik 2, daha genel düzeyde 1980-2016 arası dönem için OECD ülkeleri çerçevesinde Gini katsayısı ile ölçülen gelir eşitsizliğinin değişen eğilimini göstermektedir. Çok açık şekilde görülmektedir ki, belirtilen zaman içerisinde gelir eşitsizliğindeki artış eğilimi OECD ülkeleri için korunmuştur ${ }^{1}$.

Grafik 2. Gelir Eşitsizliğinin Zaman İçindeki Eğilimi (1980-2016)

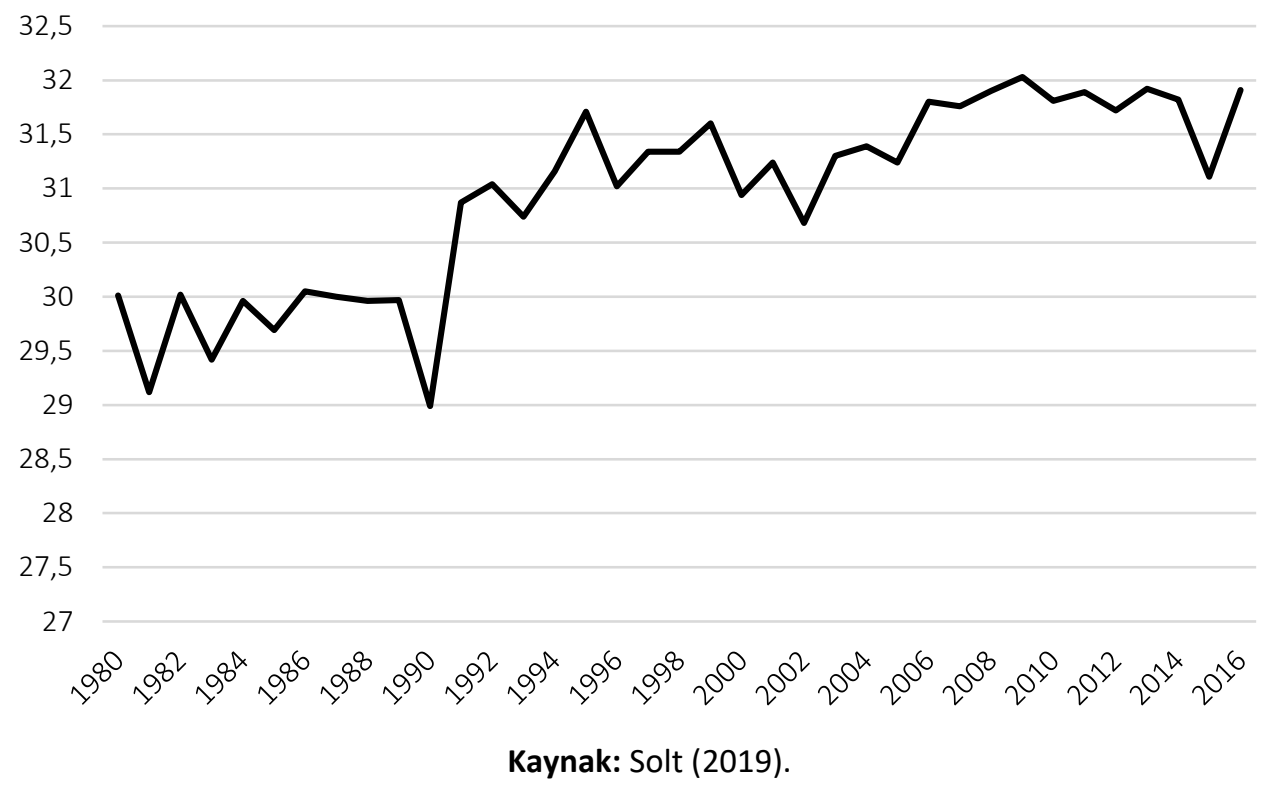

Ticaret rejiminin küreselleşme olgusuna bağlı olarak ana akım söylemde bölüşümün büyük boyutta dışlanması veya ikinci plana atılmasının ardındaki faktörler çoğunlukla iktisadi başlıklar altında yorumlanmaktadır. Ancak ana akım söylemde kendi içinde homojen bir yapıya sahip bulunmamaktadır. Mevcut perspektif açısından radikal sayılabilecek söylemlerin temelinde bölüşümde yaşanan sorunların büyük bir kısmının sermayenin küreselleşme sürecinden kaynaklandığı ve bu olgunun kurumsal düzeydeki hatalardan ve iktisadi dengesizliklerden ortaya çıktığı düşüncesi yatmaktadır. Örneğin Piketty (2014)'e göre çoğu insanın iktisadi fayda sağlayabilmesi için mali ve politik birlikteliğin sağlandığı yasal olarak düzenlenmiş bir küreselleşme yapısına intiyaç duyulmaktadır.

Bu çalışmanın ilgili yazında yer alan çalışmalardan ayrıldığı nokta temelde üç ana başlık altında toplanabilir. Illk olarak, küreselleşme olgusunun önemli bir göstergesi olan ticari açıklık değişkeninin emek ve sermaye üzerindeki etkisi sınıfsal bağlamda incelenmektedir. íkinci olarak, OECD ülkelerinin iktisadi ve sosyal gelişmişlik düzeyleri göz önünde bulundurularak emek ve sermaye arasındaki bu ikilemin boyutları emek piyasasındaki gelişmeler üzerinden analize konu edilmektedir. Son olarak, özellikle emek piyasasında meydana gelen gelişmeler çerçevesinde emeğin ulusal gelirden aldığı payın değişiminde etkisi bulunan temel göstergeler ile ticari açıklık ve ticari küreselleşme değişkenlerinin ilişkisi bütünsel bir çerçevede analize tabi tutulmaktadır.

Çalışmanın ardındaki temel motivasyonu sağlayan bu başıklar aynı zamanda çalışmanın literatüre yapacağı katkıyı şekillendiren bileşenleri de ön plana çıkarması açısından önem arz etmektedir. Bu bağlamda, mevcut bileşenler iki ayrı kategori altında sınıflandırılabilir. İlk olarak makalenin ana hedefi, 1980 sonrası dönemde yaşanan ticari küreselleşme ve daha açık bir ticari altyapı çerçevesinde sermayenin pazarlık 
gücünün artması dolayısıyla gelir dağılımının emek aleyhine bozulmasının önemini teorik ve ampirik düzeyde doğrulamaktır. Örneğin, yukarıda vurgulanan emek piyasalarında yaşanan dönüşümlere odaklanılmasının gelir eşitsizliğindeki değişimlerin makro düzeydeki analizi açısından önemli ipuçları sağlayacağı varsayılmaktadır. İkinci olarak, bölüşüm göstergesi olarak Gini katsayısının bağımlı değişken olarak analize içerilmesi makaleyi diğer çalışmalardan ayıran en önemli noktalardan birini göstermektedir. Özellikle ana akım literatür Gini katsayısını gelir dağııımı açısından analizlerinde kullanmaktan büyük oranda uzak durmaktadır. Bunun yerine bölüşüm konusunun dışında kalan kişi başına gelir ve yoksulluk değişkenlerinin kullanıldığı görülmektedir. Bu nedenle, ampirik düzeyde gelir dağılımının toplam ekonomi üzerindeki etkilerini bütünsel açıdan değerlendirmek zorlaşmakta ve soyut birtakım sonuçların ortaya çıkmasında neden olmaktadır. Grafik 3 ve Grafik 4 ise bu olguları göz önünde bulundurarak sırasıyla gelir eşitsizliği ile ticari küreselleşme ve ticari açıklık arasındaki değişimi göstermektedir.

Bölüşüm konusunun küresel dönemi ele alan farklı çıkarımlarının ticari açıklık ve ticari küreselleşme olguları etrafında tartışıldığı bu çalışmadaki temel hipotez ise ana akım literatürün bölüşüm-ticaret bağıntııının pozitif yöndeki ilişkisine bağlı bulgularının aksine ticari açıklık ve ticari küreselleşme değişkenlerinin - özellikle emek piyasasındaki politikalara bağlı olarak - emek-sermaye arasındaki ilişkileri şiddetlendirdiği ve bu bağlamda gelir eşitsizliğini artırdığı üzerine kuruludur. Özellikle ticari açıklık ve ticari küreselleşme düzeylerindeki artışın gelir eşitsizliğini hangi değişkenlere bağlı olarak etkilediği çalışmanın temel sorunsalıdır. Dabla-Norris vd. (2015: 18-19)'ne göre gelir eşitsizliğinin artmasındaki potansiyel nedenler çok farklı dinamiklere sahiptir ve bu nedenle toplumsal bütünlüğü etkileyecek gücü ellerinde bulundurmaktadır. Bu faktörleri kısaca şu şekilde sıralayabiliriz: (i) küresel eğilimler, (ii) teknolojik değişme, (iii) ticari küreselleşme, (iv) finansal küreselleşme, (v) finansal derinleşme, (vi) emek piyasası kurumlarındaki farklılaşma, (vii) yeniden-bölüşüm politikaları ve (viii) eğitim.

Grafik 3. Gelir Eşitsizliği ve Ticari Küreselleşme (1980-2016)

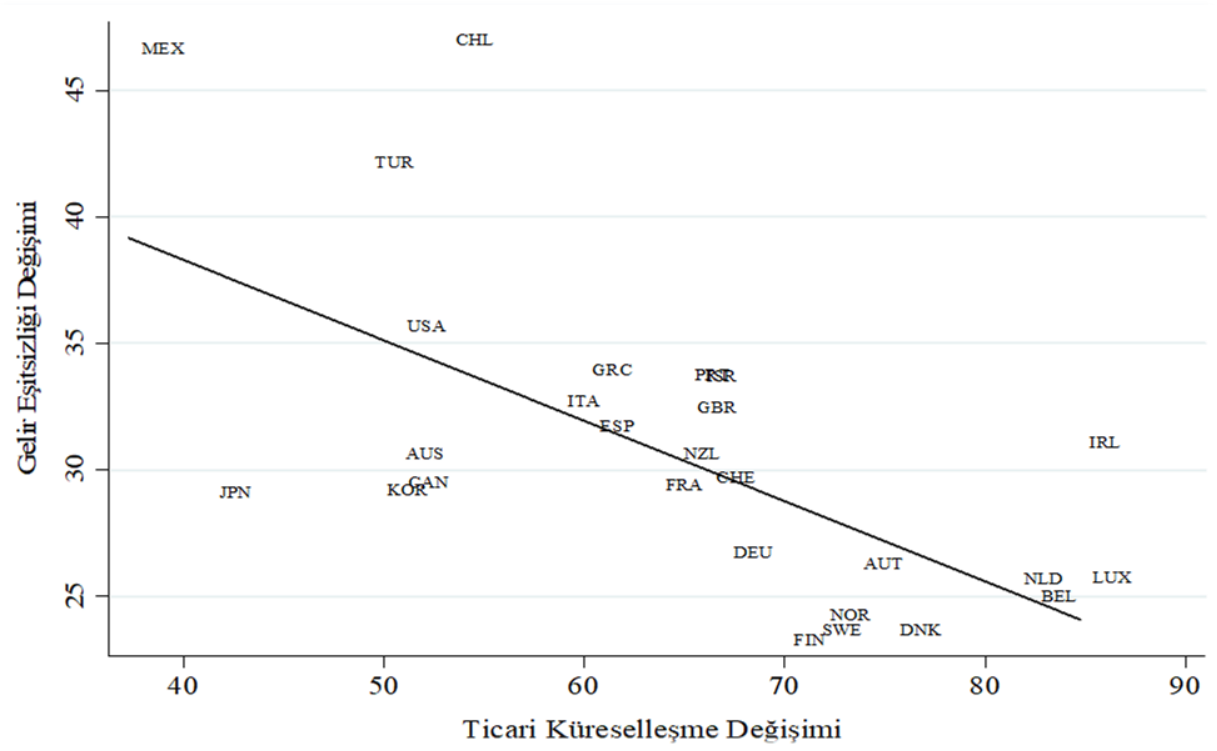

Not: Ülke kodlarının açıımları şu şekildedir: AUS: Avustralya, AUT: Avusturya, BEL: Belçika, CAN: Kanada, CHE: İsviçre, CHL: Şili, DEU: Almanya, DNK: Danimarka, ESP: İspanya, FIN: Finlandiya, FRA: Fransa, GBR: Birleşik Krallık, GRC: Yunanistan, IRL: İrlanda, ISR: İsrail, ITA: İtalya, JPN: Japonya, KOR: Kore Cumhuriyeti, LUX: Lüksemburg, MEX: Meksika, NLD: Hollanda, NOR: Norveç, NZL: Yeni Zelanda, PRT: Portekiz, SWE: İsveç, TUR: Türkiye, USA: Amerika Birleşik Devletleri. Bu ülkeler ayrıca analiz kısmında kullanılacak örneklemi oluşturmaktadır. 
Grafik 4. Gelir Eşitsizliği ve Ticari Açıklık (1980-2016)

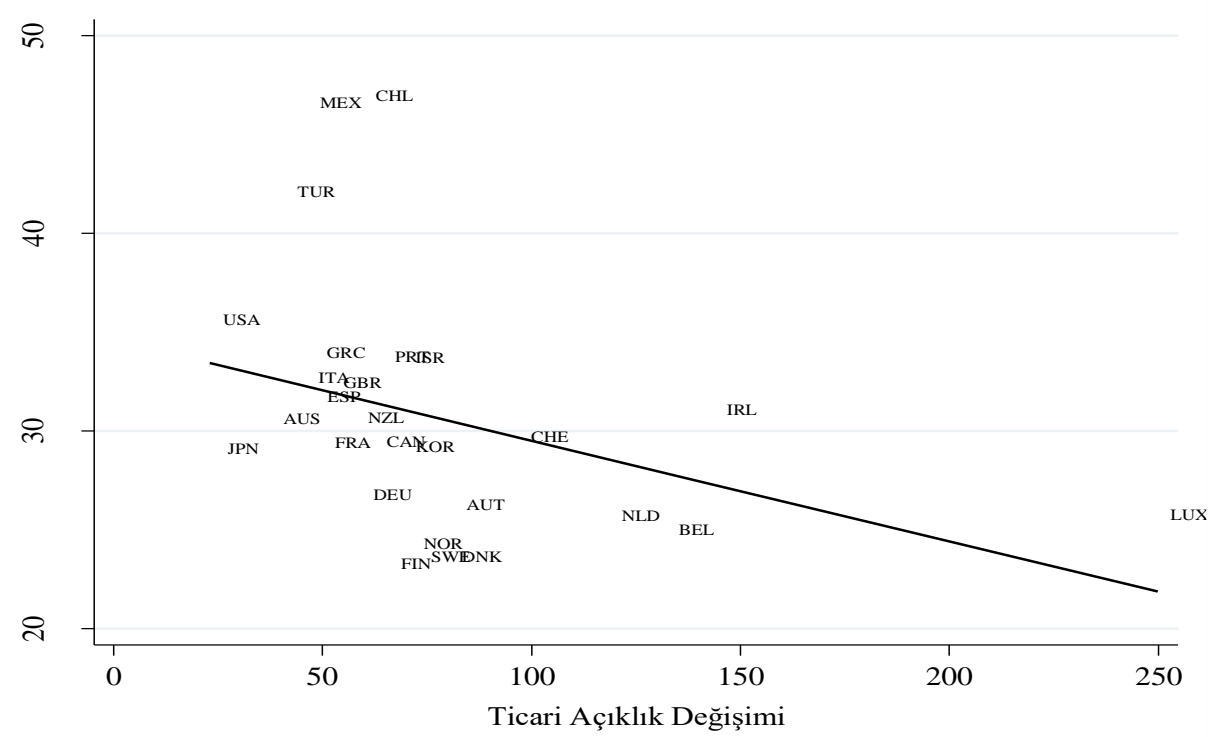

Not: Ülke kodlarının açılımları şu şekildedir: AUS: Avustralya, AUT: Avusturya, BEL: Belçika, CAN Kanada, CHE: İsviçre, CHL: Şili, DEU: Almanya, DNK: Danimarka, ESP: İspanya, FIN: Finlandiya, FRA: Fransa, GBR: Birleşik Krallık, GRC: Yunanistan, IRL: İrlanda, ISR: İsrail, ITA: İtalya, JPN: Japonya, KOR: Kore Cumhuriyeti, LUX: Lüksemburg, MEX: Meksika, NLD: Hollanda, NOR: Norveç, NZL: Yeni Zelanda, PRT: Portekiz, SWE: İsveç, TUR: Türkiye, USA: Amerika Birleşik Devletleri. Bu ülkeler ayrıca analiz kısmında kullanılacak örneklemi oluşturmaktadır.

Ancak Dabla-Norris vd. (2015) emek piyasasındaki yaşanan dönüşüm dolayısıyla emek ve sermaye arasındaki pazarlık gücünü etkileyen faktörleri gözden kaçırmaktadır. Örneğin, konu ile bağlantılı olarak Blanchard ve Giavazzi (2003) pazarlık gücü değişkenlerinin analizden çıkarılmasını dolaylı yönden eleştirmektedirler. Yazarlara göre ana akım teorik çerçeveye bağlı kalarak marjinal üretkenlikteki değişimlere odaklanmak ve böylece emek payındaki değişimleri açıklamak sınırlı ve yanlış bilgilerin ön plana çıkmasına neden olacaktır. Bu sebeple sendikalaşma gibi emek hareketlerini yansıtan değişkenlerin gelir bölüşümü analizlerine dahil edilmesi gerekmektedir. Kristal (2010) ise farklı bir argüman sunarak tarihsel faktörlerin emek-sermaye ilişkisini dönüştüren dinamiklerin başında geldiğini belirtmektedir. Daha sınırlı bir çerçeveden bakış açısı sunan Jaumotte ve Tytell (2007) ise küreselleşme ve gelir dağılımı açısından göç olgusu etkilerinin ele alınacak analize dahil edilmesini savunmaktadır. Sonuç olarak, gelir dağııımını dolaylı ve dolaysız yönden etkileyen tüm bu değişkenler ticari açıklık ve ticari küreselleşme olgularının etkileri bağlamında ampirik analiz kısmında yerini almaktadır. Önsel bir değerlendirmede bulunmak gerekirse, beklenen sonuçlar ticari açıklık ve ticari küreselleşme değişkenlerinin gelir dağıımını, emek piyasası değişkenleri özelinde meydana gelen değişimlere bağlı olarak, olumsuz yönde etkilediği ve böylece toplumsal bütünlüğü bozduğu yönündedir.

Bu çalışma ticari açıklık ve ticari küreselleşme süreçlerinde ortaya çıkan değişimlerin gelir dağılımı üzerindeki etkisini OECD ülkeleri için 1980-2016 yılları çerçevesinde mevcut süreç içerisinde emek piyasasında yaşanan dönüşümlere ve böylece sosyal ayrışma düzeyindeki farklılaşmalara bağlı olarak incelemektedir. Çalışmanın ikinci bölümünde ticari açıklık ve ticari küreselleşme ile bölüşüm bağıntısının potansiyel belirleyenleri üzerinde durularak ilgili literatür ele alınmaktadır. Üçüncü bölümde analiz kısmında kullanılacak veriler açıklanmakta ve dördüncü bölümde analizde kullanılan ekonometrik yöntem hakkında bilgi verilmektedir. Beşinci bölümde ekonometrik analize bağı ılarak ampirik sonuçlar değerlendirilmektedir. Altıncı bölümde ise ek açıklayıcı değişkenler temelinde sağlamlık testi sonuçları özetlenmektedir. Son bölüm sonuç kısmını oluşturmaktadır. 


\section{Ticari Açıklık/Küreselleşme-Bölüşüm Bağıntısının Belirleyicileri Üzerine Literatür Taraması}

Küreselleşme yazını iki farklı temel alanın birbiriyle etkileşimli olarak incelenmesi üzerine zengin bir içeriğe sahiptir. Bunlar sırasıyla ticari rejimin serbestleşmesi ve finans sektörünün liberalleşmesi olup küreselleşme olgusunun da iki güçlü ayağını oluşturmaktadır. Her ne kadar iktisadi disipline bağlı birçok çalışma bu başıkların ardındaki tarihsel ve politik belirleyenleri ortaya koymuş olsa da, sistemde yaşanan dönüşümler odaklanılan konuların içeriğini değiştirerek küreselleşme başlıklarını her dönem zenginleştirmektedir. Bu çerçevede, özellikle 2007/2008 küresel krizi sonrası bölüşümde yaşanan sorunların şiddetlenmesi araştırmaların gelir dağılımına yönelmesine ve böylece küreselleşme temelinde zengin bir içeriğin ortaya çıkmasına neden olmuştur (Bergh ve Nilsson, 2010; Asteriou vd., 2014; Doan ve Wan, 2017; Young ve Tackett, 2018). Bu alt başık küreselleşme olgusunun ticari açıklık kısmında yaşanan etkilerini gelir dağılımı ile bağlantılı olarak ele alacaktır. Diğer bir deyişle, bu araştırma bizlere ticari açıklı̆ın hangi kanallardan gelir dağılımını etkilediğini göstermesi açısından önemli ipuçları sağlayacaktır.

Literatürde emek ve sermaye arasındaki iktisadi güç ilişkilerinin ticari açıklık konusuna bağlı olarak incelenmesinin eksikliği, küreselleşmenin bu alanının bölüşüm üzerindeki etkisini açıklamada teorik yönden de mahrum bırakmaktadır. Geleneksel ticaret teorisine göre ülke içi gelir dağıımı uluslararası ticaretin gelişimine bağı olarak kaynakların kıtlığına veya bolluğuna göre farklılaşacaktır. Göreceli olarak bol kaynaklara sahip kesim ticaretin getirilerinden faydalanacak ve bölüşümü kendi çıkarlarına uygun olarak yeniden şekillendirecektir. Heckscher-Ohlin ve Stolper-Samuelson'ın teorilerine bağlı olarak mevcut görüşlerin temelinde ticaretin önündeki engellerin kaldırımasının ve daha liberal bir ticaret rejiminin benimsenmesinin vasıfsız emek talebini artırması nedeniyle gelişmekte olan ülkelerde gelir dağııımını dengeleyici bir mekanizma ile sonuçlanacağı düşüncesi yatmaktadır. Bunun en önemli sebebi gelişmiş ülkelere nazaran gelişmekte olan ülkelerde emek-sermaye oranının yüksek olmasıdır. Diğer taraftan, gelişmiş ülkelerde ise ticari açıklık düzeyi sermaye-yoğun üretimi teşvik ederek görece yüksek sermaye-emek oranı dolayısıyla vasıflı emek gücüne yönelik talep artışına yol açmaktadır. Bunun sonucunda gelişmekte olan ülkelerde vasıflı ve vasıfsız emek arasındaki ücret farkının kapanarak uluslararası düzeyde ücretlerin birbirine yakınsadığı bir durumun ortaya çıkacağı varsayılmaktadır. Gelişmekte olan ülkeler emek-yoğun ürünlerin ihracını gerçekleştirirken, gelişmiş ülkeler önceliği sermaye-yoğun ürün ihracına kaydıracaktır. Uluslararası düzlemde bunun sonucu her ülkenin üretimleri için gerekli üretim araçlarına ve kaynaklarına ulaşılacak olunmasıdır. Ayrıca, fiyatlar genel seviyesinin her ülkede birbirine yakınsaması alım gücünün artacağı bir durum ortaya çıkaracaktır. Özetlersek, emek-sermaye arasında toplam gelirin bölüşümü açısından gelişmiş ülkelerde vasıfıı emek talebine yönelik artış dolayısıyla sermaye kesimi gelirlerinin arttığı ve böylece emek payının azaldığı görülecektir. Bu nedenle, gelişmekte olan ülkelerde ise tam tersi bir sürecin işleyeceği belirtilebilir (Stockhammer, 2013; Giovannoni, 2014).

Ancak geleneksel ticaret teorileri tarafından belirtilen bu durumun 1980 sonrası dönemde geçerliliğini yitirdiği ve emek payının tüm ülke gruplarında düşüş eğilimine sahip olduğu görülmektedir ${ }^{2}$. Özellikle mevcut görüşlerin bölüşüm sorununu herhangi bir nedenden ziyade teorilerinin bir sonucu olarak görmeleri ve büyüme-bazlı olarak ticari açıklık olgusunu desteklemeleri gelir dağılımında yaşanan teorik ve pratik uyuşmazlığın ardındaki sorunu ortaya çıkarmaktadır. Dünhaupt (2017: 289)'a göre büyüme amacıyla ticaretin uluslararası bir nitelik kazanması gelir dağılımını iki faktöre bağlı olarak olumsuz yönde etkilemektedir. Bunlar sırasıyla küresel rekabet ve ticarete konu olan ürünlerin fiyatlarıdır. lilk olarak, küresel rekabet artışı uluslararası alanda fiyat rekabetini de teşvik ederek firmaları ileri-teknoloji üretim tekniklerini kullanmaya yönlendirerek birim başına maliyetleri düşürme yoluyla ortalama fiyat azalışına neden olacak ve böylece vasıfsız emek kesimine yönelik talep azalarak emek payı üzerinde olumsuz bir etki yaratacaktır. İkinci olarak, eğer ticarete konu olan mal ve hizmetlerin fiyatı talep gören ülkedeki emek maliyetlerinden yüksek düzeye sahipse sermayenin hem parasal hem de üretim açısından hareket serbestisinin artması sonucu emek payını azaltacaktır.

Ticari açıkık söyleminin gelir dağııımı üzerindeki büyüme odaklı etkisinin araştııılmaya konu edilmesi gereken noktalarının ortaya çıkarılması, iki temel değişken arasındaki değişimin ardında yatan unsurların anlaşılması açısından gerekli bulunmaktadır. Bununla bağlantılı olarak, emek ve sermaye arasındaki güç ilişkilerinin rolü bu çerçevede üzerinde durulmayı gerektirmektedir. Küreselleşmenin büyüme kanalı özünde 
çalışanların nitelik yapısındaki değişimleri gizleyerek gelir bölüşümündeki değişimi şiddetlendiren "vasıf primi" (skill premium) faktörünün teorik altyapıdan dışlanmasına neden olmaktadır. Yay vd. (2016: 583)'ne göre, belirtilen faktörün uluslararası alanda artan değeri farklı iktisadi kanallardan (örn. alım-gücü farklılıkları, dış kaynak kullanımı, faktör gelirleri ve ürün fiyatları arasındaki farklııı, yüksek teknoloji transferi ve doğrudan yabancı yatırımlar) etkisini gösterme gücüne sahip olup bölüşüm açısından incelenmesi gerekmektedir.

Ilk olarak, ticaret alanında uygulanan dışa açık iktisadi politikalar ve böylece belirli ürünlerde uzmanlaşma stratejisi ülkeler arasındaki alım gücü farklılıklarına bağlı olarak geleneksel argümanları olumsuzlayabilir. Bunun ardında yatan temel düşünce, alım gücü farklılıkları dolayısıyla talep yapısının değişmesi ve bu durumun fiyatlar üzerinde negatif etkide bulunmasıdır. Ayrıca alım gücüne bağlı olarak, gelir seviyesi düşük ülkeler emek-yoğun ürün talebine yönelirken yüksek gelirli ülkeler sermaye-yoğun ürünleri talep edeceklerdir. Emek gücünün niteliği çerçevesinde vasıflı ve vasıfsız işgücü arasındaki gelir farklııklarını daha da derinleştirmesi nedeniyle alım gücü farklıııları uluslararası ticarette dengelenme sürecini aksatan bir yapının ortaya çıkmasına yol açabilir.

İkinci olarak, ticari açıklık olgusunun büyüme ile bağlantılı bir diğer boyutu "küresel değer zinciri" başlı̆ı altında incelenebilir (Dao vd., 2017: 18-21). Gelişmiş ülkelerde bu durum sermayenin dışa yönelmesi ve üretimin kıyı ötesi ülkelere kayması olarak ortaya çıkarken (Amiti ve Wei, 2009), gelişmekte olan ülkelerde tekrar ihraç etme politikaları ile ön planda tutulmaktadır (Hummels vd., 2014; Koopman vd., 2014). Ancak buradaki asıl sorun küresel değer zincirinde yaşanan değişimlere paralel olarak işgücü niteliğinde yaşanan farklılaşmalardır. Feenstra ve Hanson (1996) tarafından belirtildiği gibi, üretim sürecinin farklı aşamalara bölünmesi ve ara malı üretiminin farklı alanlara kayması gelişmişülkelerde üretim sürecindeki vasfın artışını teşvik etmektedir. Bu nedenle, üretimin küresel bir nitelik kazanarak bütünleşme sürecini hızlandırması, vasıfsız emek gücünün ücretlerini aşağı yönlü baskılayarak gelir dağııımını olumsuz etkilemekte ve bu kesimi düşük getirili yatırım alanlarına ve niteliksiz işlere yönlendirmektedir. Üretimin ara aşamalarının büyük bölümü maliyet avantajı ortaya çıkaracak alanlara transfer edilerek sermaye getirisi üzerinde pozitif bir etki yaratılmaya çalışılmaktadır (Grossman ve Rossi-Hansberg, 2008).

Üçüncü olarak, sektörler arası faktör dağılımı konusunda geleneksel bakış açısının tersine ortaya çıkan bölüşüm ile ilgili sorunlar temelde ürün fiyatları ve faktör kazançları arasındaki ilişkiye bağlı olarak şekillenmektedir. Ana akım görüşler ticarette daha liberal bir ekonomi politikası izlenmesinin emeğin sektörler arası dağılımını üretimin gereklerine göre tekrar düzenleyerek ücret dağılımını optimum düzeye getireceği üzerine kuruludur. Ancak Goldberg ve Pavcnik (2007)'e göre bu durumun öncelikli koşulu emek piyasalarının katı (rigid) bir yapıya sahip olmamasına bağılı bulunmaktadır.

Dördüncü olarak, küresel düzeyde rekabetin şiddetlenmesi, uluslararası piyasalarda firmaları ileri teknoloji bazlı üretime yönlendirerek üretkenlik artışı talebini, eğitim düzeyinde ve niteliğinde gelişimi ve böylece vasıf primlerinde artışı teşvik ederek gelir eşitsizliğini yükseltici bir etki yaratmaktadır. Dabla-Norris vd. (2015: 18-19)'ne göre bilgi teknolojilerindeki gelişmeler ve bunun sonucunda üretkenlik ve vasıf primindeki artışlar belirtilen olguların ortaya çıkması ile sonuçlanarak emeğin gelir payını olumsuz yönde etkilemektedir. Örneğin, teknoloji düzeyinde meydana gelen farklılaşmalar ve firmaların artan rekabet dolayısıyla daha ileri teknoloji ürünleri üretmeye yönelmeleri sektörler arasında vasıflı emek talebini artırarak vasıfsız emeğin daha ucuz maliyetli alanlara kaymalarına neden olmaktadır. Bunun sonucunda rekabetin ekonomiler arasındaki yayılma hızına bağı olarak küresel ortamda gelir dağııımını vasıfsız emek aleyhine etkileyecek koşulların ortaya çıkması olası hale gelmektedir. Özellikle üretimde otomasyon tekniklerinin yerleşmesi ve ilerlemesi ve ayrıca üretimin robotlaşma düzeyindeki artış mevcut dinamik süreçlerin hızlanmasını beraberinde getirmektedir.

Son olarak, finansal alanda sermaye akışlarında yaşanan düzey artışları doğrudan sermaye yatırımları kanalıyla ücretleri aşağı çeken mekanizmayı harekete geçirerek gelir dağılımını olumsuz yönde etkilemektedir. Buradaki temel motivasyon teknoloji transferleri dolayısıyla vasıflı emek talebindeki artışın hızlanması ve ülkeler arasındaki sektörel bazda faktör gelirlerinin farklılaşmasıdır. Özellikle sermaye 
akışlarındaki artış vasıtasıyla ileri otomasyona sahip üretim teknikleri ülkelerin daha fazla kaynağa sahip olarak rekabetin potansiyel olarak şiddetlenmesine neden olmaktadır.

Sıralanan tüm bu başlıklar ticari açıklık konusunda neoklasik yaklaşımın gelir dağılımı üzerinde ortaya çıkabilecek olumsuz yönlerini göstermesi açısından üzerinde düşünülmeyi gerektirmekte ancak teorinin kendisini eleştirmekten uzak durmaktadır. Bu nedenle, öncelikli ele alınması gereken nokta neoklasik ticaret teorisinin varsayımları çerçevesinde gelir dağılımını hangi durumların etkileyebileceğinin ortaya çıkarılması ve ampirik çalışmalar temelinde bu karşıt göstergelerin incelenmesidir. Illk olarak, faktör akışkanlığının sabit olduğu varsayımı artan sermaye akışkanlığı ve dolayısıyla emeğin ülkeler arasında serbest bir şekilde yer değiştirmesi olguları ile çelişmektedir (European Commission, 2007). íkinci olarak, emek kesimi kendi içinde homojen bir yapıya sahip değildir. Özellikle teknoloji bazlı üretimin teşvik edilmesi ve rekabet artışının şiddetlenmesi emek kesiminin vasıf durumlarının önemini vurgulamakta olup gelişmiş ve gelişmekte olan ülkeler arasında emek kazançlarını farklılaştırmaktadır (Stockhammer, 2009). Üçüncü olarak, üretimin ilerlemesi, küresel rekabet artışı, emeğin niteliği çerçevesinde dönüşüme uğrayan talep yapısı ve böylece gelir dağılımında yaşanan olumsuzluklar toplam ekonomi içerisinde devlet müdahalesinin gerekli durumlarda önünü açmaktadır (Roine vd., 2009). Son olarak, küresel ve bölgesel temelde yaşanan ekonomik şoklar ve sermaye akışlarına bağı olarak ortaya çıkan iktisadi dalgalanmalar gelir dağııımını bozucu faktörlerin etkisini artırmaktadır. Ticari açıklıkta yaşanan düzey artışları burada en önemli kanalı oluştururken, faktör dağılımını ürün ticareti vasıtasıyla dönüştürmektedir.

Yukarıda belirtilen teorik çıkarımlar ticari açıklık ve gelir dağııımı arasındaki ilişki bağlamında ortak bir sonucun bulunmadığını göstermekte olup ampirik çalışmaların da kapsam olarak geniş bir boyutta değerlendirilmesi gerektiğini önsel olarak belirtmektedir. Diğer bir deyişle, teorik çalışmalarda ortaya çıkan bütünsellik sorunları, ampirik çalışmalarda da yansımasını bulmaktadır. Örneğin, Kraay (2006) ve Goldberg ve Pavcnik (2007) ticari açıklık ile gelir eşitsizliği arasında pozitif bir ilişkinin bulunduğunu belirtmektedir. Wood (1995)'a göre vasıfsız emek tarafından kazanılan gelirler ticaret rejiminde yaşanan liberalleşme yanlısı ekonomi politikalarından olumsuz etkilenirken, Sebastian (1997) bu durumun sadece gelişmiş ekonomiler için geçerli olduğunu belirtmektedir. Toplam ulusal gelirden emek kesimine giden pay ile ticari payda yaşanacak bir artışın birbirini olumsuz yönde etkileyeceğini belirten Harrison (2005) ve Guscina (2006) ortak bir zeminde buluşmaktadır. Ancak doğrudan yabancı yatırımların temel alındığı çalışmalar açısından farklı durumların ortaya çıktığı görülebilmektedir. Örneğin, Decreuse ve Maarek (2015) doğrudan yabancı yatırım akışlarında ortaya çıkabilecek artışların emek payını azalttığını vurgularken, dışa akış yönünden doğrudan yabancı yatırımların sanayisizleşme sürecini hızlandırarak gelişmiş ülkelerde ücret ayrımını derinleştirdiğini belirten Alderson ve Nielsen (2002) ise konuyu daha spesifik açıdan analiz etmektedir. Dış akış temelinde doğrudan yabancı yatırımlara ek olarak iç akışlarının da ücret eşitsizliğini artırıcı bir etkisi olduğunu belirten Brady ve Wallace (2000) konunun farklı bir yönden ele alınması gerektiğini göstermektedir. Bigsten ve Munshi (2014) ortalama gelirler açısından daha düşük düzeylerde bulunan OECD ülkelerinde farklı meslekler arası ücret oranlarının ticaret rejiminin küresel bir nitelik kazanması sonucu olumsuz yönde etkilendiğini belirtmektedir. Rodrik (1997) faktör akışkanlığının önemine dikkat çekerek ülkeler arasında emek serbestisine daha yüksek oranlarda sahip olan çalışanların ticari yönde uygulanan liberal ekonomi politikalardan olumlu olarak etkilendiğini göstermektedir. Gourdon vd. (2008) eğitim düzeyi düşük çalışanların oransal olarak yüksek olduğu düşük gelirli ülkelerde gümrük vergisinin düşürülmesinin gelir eşitsizliğini artırıcı yönde bir etkide bulunacağını söylemektedir. Son olarak, Meschi ve Vivarelli (2009) gelişmekte olan ülkelerin yüksek ticaret hacmine sahip gelişmiş ülkelerle alışverişte bulunmasının gelir eşitsizliğini olumsuz etkilediğini belirtmektedir ${ }^{3}$.

\section{Veri Seti}

Bu bölüm ampirik analiz içerisinde kullanılacak değişkenleri açıklamaktadır. Mevcut araştırmanın içeriği konunun toplumsal konumu itibarıyla iktisadi değişkenlerin yanı sıra sosyal verileri de içermesi açısından geniş bir analize kapı aralamaktadır. Bu çerçevede ilk olarak gelir bölüşümünü ölçmek için hanehalkı düzeyinde oluşturulan Gini katsayısı ele alınacaktır. Solt (2019) tarafından oluşturulan Gini katsayısı The Standardized World Income Inequality Database (SWIID) 8.1 versiyonu üzerinden elde edilmiş olup, birçok 
ülke için panel veri analizlerinde kapsamlı bir içeriğe sahip bulunmaktadır. Özellikle gelişmekte olan ülke grupları için Gini katsayısının elde edilebilirliğinde yaşanan veri sıkıntısı mevcut veri tabanı sayesinde büyük ölçüde çözüme kavuşmaktadır. Gelir dağııımını inceleyen panel veri analizine bağlı çalışmaların çoğu analiz kısmında Gini katsayısına ulaşmalarındaki aksaklıklar ve serilerin zaman içerisinde eksik olması dolayısıyla araştırmalarının kapsamını daraltmaktadır. Bu durum özellikle gelir dağılımı konusunda bütünsel bir çıktı ortaya çıkarmak adına sıkıntı yaratmakta ve hatta çoğu durumda yanlış yorumların yapılmasını beraberinde getirmektedir. Bu nedenle, araştırmacıların çoğu Gini katsayısına ulaşılabilir ülkeleri seçerek analizlerini yapmaktadır. Sonuç olarak, en eksik durumda bulunan az gelişmiş ve bazı gelişmekte olan ülkeler gelir dağılımı ile ilgili analizlerin dışında tutulmaktadır. Bu bağlamda Solt (2019)'un çalışması, belirtilen bu kategorilerde bulunan ülkelerin de analize içerilebilmesini sağlaması nedeniyle büyük bir önem taşımaktadır. Teorik düzeyde ise Solt (2019)'un Gini katsayısına ait veri içeriği gelir dağılımını vergi öncesi (pre-tax transfer) ve vergi sonrası (post-tax transfer) olarak iki ayrı seri biçimde sınıflandırmaktadır. Vergiler düşüldükten sonra harcanabilir gelirler üzerinden elde edilen Gini katsayısı (Gini_Net) bu çalışmanın gelir bölüşümünü analiz etmede kullanılacak bağımsız değişkeni betimlemektedir. Her ne kadar Solt (2019)'a göre SWIID veri tabanı Gini katsayısının içeriğini genişletmesi bağlamında birçok ülke grubunun analizlere dahil edilebilmesine olanak sağlasa da ülkeler arasında gelir eşitsizliklerinin ham düzeyde ele alınmasındaki sorunlar belli sosyoekonomik ve politik koşullara bağlı olarak devam etmektedir. Bu durumun göz önünde tutulduğu SWIID veri tabanı, Gini katsayısına yönelik tahminlerin standart hatalarını ayrıca ele almakta ve böylece araştırmacıları ülkeler arası kıyaslamalar yaparken bu tür sorunların varlığını yansıtmaya yönelik önemli ipuçları sağlamaktadır ${ }^{4}$ (Solt, 2016: 14).

İkinci olarak, ticari küreselleşme olgusunun ölçümü mevcut çalışmanın analiz kısmındaki bir diğer önemli sorunu ortaya koymaktadır. Öncelikle, ticari küreselleşme veya ilgili yazındaki bir diğer tanımlanmasıyla ticari açıklık olgusu çok farklı ölçüm tekniklerini içerisinde barındırmaktadır ${ }^{5}$. Bu çalışmada ele alınacak ticari küreselleşme/açıklık değişkeni ise üç farklı ölçüm boyutu ile analize dahil edilecektir. İlk sırada KOF Globalization veri tabanından elde edilen ticari küreselleşme endeksi bulunmaktadır. 0 ile 100 arasında değer alan ticari küreselleşme endeksi sırasıyla otarşi ve ticari işlemlere tamamen açıklık durumlarını betimlemektedir. Diğer bir ifadeyle, daha yüksek değerler ülkelerin ticari hesaplarının yabancı işlemlere açıklığının arttığı anlamına gelmektedir. Tam tersi durum ise ülkelerin ticari olarak içlerine kapandığını ve ürünlerin ülke içinde üretildiği ithal ikameci bir konuma doğru evrildiğini betimlemektedir ${ }^{6}$. Ikinci olarak, ticari küreselleşme/açıklık olgusunu ölçmek için kullanılacak bir diğer değişken World Development Indicators (WDI) Database üzerinden elde edilen ihracat ve ithalat hacimlerinin toplamının katma değere oranı olarak hesaplanmaktadır. Kısaca, nominal ticari açıklık değişkeni olarak adlandırılacak olan mevcut değişken toplam katma değerdeki fiyat değişimlerini el almaması dolayısıyla ilgili yazında eleştirilere maruz kalmaktadır. Bu sorunun varlığını göz önünde tutarak ticari küreselleşme/açıklık ile ilgili olarak üçüncü bir değişken daha ayrı olarak analize dahil edilmektedir. Reel ticari açıklık değişkeni olarak adlandırılan bu değişken nominal ticari açıklık değişkeninin Penn World Tables (PWT) 9.1 veri tabanından elde edilen toplam ulusal üretim değerinde yaşanan yıllar içindeki fiyat değişimlerinin endeks haline getirildiği değişkenden arındırılması ile elde edilmektedir. Bu nedenle, reel olarak ticaret kanalında ortaya çıkan uluslararası ölçekli değişimleri daha sistematik ve doğru bir biçimde yansıtması dolayısıyla farklı açılardan diğer değişkenlere göre üstünlüğe sahip bulunmaktadır.

Üçüncü olarak, gelir dağılımını etkileyen unsurların başında emek piyasası özelinde bulunan değişkenlerin ele alınması gerekmektedir. Bu bağlamda, sağlamlık testi kapsamında emek piyasasını dolaylı ve dolaysız yönden etkisi altında bulunduran dört farklı kontrol değişkeni mevcut analiz içerisinde kullanılacaktır. Bu değişkenler sırasıyla şu şekilde sıralanabilir: (i) istihdam oranı, (ii) ortalama çalışma saati, (iii) işgücüne katılım oranı ve (v) beşeri sermaye endeksi. Tüm bu değişkenler ülkelerin sosyo-iktisadi ve toplumsal yapılarına göre çok farklı teorik açıklamalara sahip olsalar da, her bir değişkenin emek piyasalarında rolünün belli bir dereceye kadar bulunduğu varsayılmaktadır. Bu nedenle, sağlamlık testi kapsamında analiz içerisine dahil edilerek ticari küreselleşme/açıklık-bölüşüm bağıntısını hangi yönlerden etkiledikleri incelenecektir. 
Son olarak, tüm bu değişkenlerin yanı sıra, analiz kısmında ticari küreselleşme ve bölüşüm arasındaki ilişki makro temelli ek açıklayıcı değişkenlerinin modele içerilmesi ile test edilecektir. Bunlar sırasıyla şu şekilde belirtilebilir: (i) finansal küreselleşme endeksi, (ii) devlet harcaması (\% GSYH), (iii) yabancı sermaye yatırımı, dış akış (\%GSYH), (iv) kişi başına GSYH büyüme oranı (\% yıllık) ve (v) refah ölçeğinde toplam faktör verimliliği endeksi. Bu verilerin tümü mevcut ilişkiyi belli oranlarda etkileme potansiyeline sahip olsa da, aralarında finansal küreselleşme endeksinin önemli bir yeri bulunmaktadır. Öncelikle, küreselleşme olgusunun bir ayağı ticari küreselleşme ise diğer bir ayağı da finansal küreselleşmedir. Bu nedenle, her iki değişken birbirini tamamlayıcı özellikleri içlerinde taşımaktadır. İlgili yazın içinde mevcut bulunan ticari küreselleşme üzerine ampirik analizlerin birçoğu bu ilişkiyi görmezden gelerek küreselleşmenin iki temel ayağından birini analiz dışı tutmaktadır. Bu durumun en önemli sonucu ise küreselleşme olgusunun bir bütün halinde ele alınamaması ve ayrıca eksik bulgular çerçevesinde küreselleşme olgusunun farklı yönlerinin yorumlanmasıdır. Tüm bu varsayımlar altında, mevcut çalışma içerisinde her iki değişkende sağlamlık testi çerçevesinde analize tabi tutulacaktır.

Tablo 1. Analiz Kısmında Kullanılan Veriler ve Kısaltmaları

\begin{tabular}{|c|c|c|}
\hline Kısaltma & Veri & Kaynak \\
\hline loggini & $\begin{array}{c}\text { Logaritmik Ölçekte Gelir Eşitsizliği } \\
\text { Katsayısı }\end{array}$ & Solt (2019), Yazarların Kendi Hesaplaması \\
\hline logtrglob & $\begin{array}{l}\text { Logaritmik Ölçekte Ticari Küreselleşme } \\
\text { Endeksi }\end{array}$ & KOF Globalization Index, Yazarların Kendi Hesaplaması \\
\hline logtropen & $\begin{array}{c}\text { Logaritmik Ölçekte Nominal Ticari Açıklık } \\
\text { Oranı }\end{array}$ & $\begin{array}{l}\text { World Development Indicators, Yazarların Kendi } \\
\text { Hesaplaması }\end{array}$ \\
\hline logadjtropen & $\begin{array}{c}\text { Logaritmik Ölçekte Reel Ticari Açıklık } \\
\text { Oranı }\end{array}$ & $\begin{array}{c}\text { World Development Indicators, PWT } 9.1 \text { Yazarların Kendi } \\
\text { Hesaplaması }\end{array}$ \\
\hline logfinglob & $\begin{array}{l}\text { Logaritmik Ölçekte Finansal Küreselleşme } \\
\text { Endeksi }\end{array}$ & KOF Globalization Index, Yazarların Kendi Hesaplaması \\
\hline govgdp & Devlet Harcaması (\% GSYH) & World Development Indicators \\
\hline fdiout & $\begin{array}{c}\text { Yabancı Sermaye Yatırımı, Dış Akış (\% } \\
\text { GSYH) }\end{array}$ & World Development Indicators \\
\hline percapita & Kişi Başına GSYH Büyüme Oranı (\% Yıllık) & World Development Indicators \\
\hline logexpgdp & Logaritmik Ölçekte İhracat Oranı (\% GSYH) & $\begin{array}{l}\text { World Development Indicators, Yazarların Kendi } \\
\text { Hesaplaması }\end{array}$ \\
\hline logimpgdp & Logaritmik Ölçekte İthalat Oranı (\% GSYH) & $\begin{array}{l}\text { World Development Indicators, Yazarların Kendi } \\
\text { Hesaplaması }\end{array}$ \\
\hline tech & Refah Ölçeğinde Toplam Faktör Verimliliği & PWT 9.1 \\
\hline logemp & $\begin{array}{c}\text { Logaritmik Ölçekte Toplam İstihdam } \\
\text { Miktarı }\end{array}$ & PWT 9.1, Yazarların Kendi Hesaplaması \\
\hline logavh & $\begin{array}{l}\text { Logaritmik Ölçekte Ortalama Çalışma } \\
\text { Saati }\end{array}$ & PWT 9.1, Yazarların Kendi Hesaplaması \\
\hline labforce & İşgücüne Katılım Oranı (\%) & World Development Indicators \\
\hline humancap & Beşeri Sermaye Endeksi & PWT 9.1 \\
\hline crisis & 2008/2009 Küresel Krizi Kukla Değişkeni & Yazarların Kendi Hesaplaması \\
\hline
\end{tabular}

Özet olarak, Tablo 1 analiz kısmında kullanılacak verileri, kısaltmalarını ve ilgili kaynaklarını göstermektedir. Buna ek olarak, Tablo 2 ise mevcut değişkenlerin özet istatistiklerini sunmaktadır. Analiz kısmında kullanılan tüm bu değişkenlerin çeşitliliği ve farklı iktisadi sınıflandırmalar içerisinde değerlendirilebilmeleri mevcut çalışmanın içeriğinin geniş bir çerçevede ele alınabilmesini sağlamaktır. Bu nedenle, çalışmanın ekonominin herhangi belli bir yönüne odaklanılarak değerlendirilmesinden kaçınılması planlanmaktadır. Bir sonraki bölüm çalışmada uygulanan ampirik yöntemlerin açıklanmasına ayrılacak olup bu yöntemler çerçevesinde kurulacak modelin spesifikasyonu ele alınacaktır. 
Tablo 2. Özet İstatistikler

\begin{tabular}{ccccccc}
\hline \hline Kısaltma & Ortalama & Medyan & Max. & Min. & Standard Hata & Gözlem Sayısı \\
\hline loggini & 3,41 & 3,40 & 3,88 & 3,01 & 0,19 & 999 \\
logtrglob & 4,12 & 4,17 & 4,53 & 3,04 & 0,26 & 999 \\
logtropen & 4,13 & 4,11 & 6,03 & 2,77 & 0,53 & 999 \\
logadjtropen & 3.87 & 3,89 & 6,36 & 1,61 & 0,78 & 999 \\
logfinglob & 4,24 & 4,32 & 4,59 & 3,34 & 0,25 & 999 \\
govgdp & 18,41 & 18,68 & 38,24 & 7,51 & 4,65 & 999 \\
fdiout & 3,89 & 1,41 & 158,45 & $-7,87$ & 10,26 & 956 \\
percapita & 1,86 & 1,90 & 23,94 & $-12,37$ & 2,80 & 999 \\
logexpgdp & 3,44 & 3,40 & 5,41 & 1,64 & 0,57 & 999 \\
logimpgdp & 3,43 & 3,41 & 5,25 & 1,93 & 0,51 & 999 \\
tech & 0,97 & 0,98 & 1,55 & 0,67 & 0,09 & 999 \\
logemp & 6,88 & 6,72 & 8,18 & 5,20 & 0,59 & 999 \\
logavh & 3,25 & 3,25 & 3,46 & 3,13 & 0,12 & 999 \\
labforce & 59,38 & 60,08 & 84,52 & 38,4 & 6,85 & 999 \\
humancap & 3,02 & 3,09 & 3,77 & 1,47 & 0,46 & 999 \\
\hline \hline
\end{tabular}

\section{Ekonometrik Yöntem}

Ticari küreselleşme/açıklık ve bölüşüm arasındaki ilişkiyi incelemek için çalışmanın dayandığı temel yöntem panel veri analizi olacaktır. Bu çerçevede hem temel analiz hem de sağlamlık testleri çerçevesinde üç ayrı yönteme dayalı olarak mevcut ilişki ele alınacaktır. Bu yöntemler kısaca şu şekilde sınıflandırılabilir: (i) sabit etkili (FE) panel veri modeli, (ii) genelleştirilmiş momentler metodu (Generalized Method of MomentsGMM) ve (iii) Anderson ve Hsiao (1982) tarafından oluşturulan araç değişken (Instrumental Variables-IV) metodu. illk olarak, sabit etkili panel veri modeli çerçevesinde ticari küreselleşme/açıklık-bölüşüm bağıntısı Denklem (1)'deki şekliyle ifade edilebilir:

$$
\operatorname{LOGGINI}_{i t}=\bar{\beta}+\alpha_{i}+\beta_{2 i t} L_{O G T R A D E} E_{2 i t}+\cdots+\beta_{k i t} \text { KONTROL }_{k i t}+u_{i t}
$$

Denklem (1)'de $\bar{\beta}$ terimi ortalama sabiti terimi, $\bar{\beta}+\alpha_{i}$ birimlere ait sabit terimi, LOGGINI değişkeni logaritmik ölçekte Gini katsayısını, LOGTRADE değişkeni logaritmik ölçekte ticari küreselleşme ve ticari açıklık verilerini, KONTROL değişkeni açıklayıcı ve tüm diğer kontrol verilerini ve $u$ ise hata terimini göstermektedir. Ayrıca $\alpha_{i}$ kendi başına gözlemlenemeyen birimlere ait etkileri ve birimler arası ortalama sabit terimden farklılığı ifade etmektedir. Bu açıdan $\alpha_{i}$ teriminin varlığı panel veri modeli seçiminde sabit veya rassal etkili modellerin seçiminde temel gösterge niteliğindedir. Sabit veya rassal modellerin belirlenmesindeki en önemli kriter $\alpha_{i}$ teriminin tahmin edilen bir parametre mi yoksa herhangi bir dağılım sonucu elde edilen stokastik bir parametre mi olduğudur. Eğer $\alpha_{i}$ terimi ilk durumdaki gibi tahmin edilen bir parametre ise sabit etkili modellere, ikinci durumdaki gibi ana kütleden çekilen panele bağlı stokastik bir parametre ise rassal etkili modellere referans verilebilir. Ayrıca, belirlenecek panel veri modelinin türü modelin tahmin edilmesindeki amaca bağlı olarak da oluşturulabilir. Son olarak, açıklayıcı değişkenler ile $\alpha_{i}$ terimi arasındaki korelasyonun mevcut olması da modelin seçiminde belirleyici bir kriter olarak ele alınabilir. Eğer aralarında herhangi bir korelasyon varsa, sabit etkiler tahmincisi tutarlı kabul edilerek model seçimi belirlenir. Ancak eğer korelasyon zayıf veya yoksa tahminciler tutarlı olup hem sabit hem de rassal etkili tahminciler regresyon analizlerinde kullanılabilir. Ancak ikinci durumda rassal etkili tahmincilerin daha tutarlı olduğu varsayılabilir. Bu olgu Hausman testinin varlığının ön koşulu olarak belirtilebilir (Tatoğlu, 2016: 167).

İkinci olarak, sabit etkili panel veri modelinin yanında genelleştirilmiş momentler metodu diğer bir yöntem olarak analiz içerisinde ele alınacaktır. GMM yönteminin öncelikli amacı mevcut modelde uygulanması sonucu elde edilen GMM tahmincisi yoluyla modelin dinamik yapısını öne çıkarak endojenlik sorununu çözmektir. Bu nedenle, sabit ve rassal etkili model tahmincilerine göre daha tutarlı ve etkin tahminciler elde edilmesini sağlamaktadır. Mevcut modelin dinamik yapısı bağımlı değişkenin gecikmeli 
değerlerini açıklayıcı değişken olarak regresyon tahmini içerisine dahil edilmesini gerektirmektedir. Bu yönüyle Denklem (2) GMM yöntemine bağlı dinamik modeli ifade etmektedir (Baltagi, 2005):

$$
\text { LOGGINI } i t=\theta L O G G I N I_{i t-1}+X_{i t}^{\prime} \beta+u_{i t}
$$

$\theta$ vektörel bir büyüklüğü, $X_{i t}^{\prime}$ ise $1 \times$ k boyutlu bir matrisi göstermektedir. $u_{i t}$ tek yönlü hata terimidir. Denklem (3) tek yönlü hata terimini daha detaylı olarak tanımlamaktadır:

$$
u_{i t}=\mu_{i}+v_{i t}
$$

$\mu_{i} \sim \operatorname{IID}\left(0, \sigma_{\mu}^{2}\right)$ ve $v_{i t} \sim \operatorname{IID}\left(0, \sigma_{v}^{2}\right)$ olarak tanımlanan hata terimine ait varsayımların sıfır ortalamaya, sabit varyansa ve birbirlerinden bağımsız olduğuna dayanmaktadır. Bu koşullar çerçevesinde GMM yöntemine bağlı dinamik modelde tüm açıklayıcı değişkenler katı dışsal olarak kabul edilmektedir.

Son olarak, GMM modelinin yanı sıra Anderson ve Hsiao (1982) tarafından oluşturulan araç değişken yöntemi regresyon tahmininde kullanılacak bir diğer yöntemi göstermektedir. $u_{i t}$ bireysel etkileri içermesi nedeniyle Denklem (3) içerisinde bağımlı değişken LOGGINI ${ }_{i t}$ hata terimi ile ilişkili kabul edilebilir. Bu nedenle, GMM modelinde $L O G G I N I_{i t-1}$ dolaylı olarak $u_{i t}$ ile ilişkili sayılmaktadır. Sabit ve rassal etkili modeller içerisinde kullanılan bağımlı değişkenin endojenlik sorununu çözmek için gecikmeli değerlerinin açıklayıcı değişken olarak regresyona dahil edilmesi durumunda eğer gecikmeli değerler ile hata terimi arasında korelasyon varsa elde edilen tahminciler hatalı katsayılar elde edilmesine neden olacaktır (Greene, 2003). Örneğin, OLS tahmincileri böyle bir durumun varlığında yanlı ve tutarsız sonuçlar verir (Baltagi, 2005). Bu sorunu ortadan kaldırmak için bağımlı değişkenin gecikmeli değeri yerine araç değişken kullanılması yeni bir yöntem olarak teknik alanda yerini almaktadır. Anderson ve Hsiao (1982) tarafından oluşturulan bu yönteme göre değişkenlerin birinci farkları alınarak birim etkinin regresyon sonuçlarından dışlanacağı öne sürülmektedir. Baltagi (2005: 135-136) birinci fark dönüşümü yoluyla bağımlı değişken ile hata payı arasındaki korelasyonun kolaylıkla incelenebileceğini belirtmektedir. Anderson ve Hsiao (1982)'nun araç değişken kullanımına yönelik sorun hata payının birinci farkı ile kullanılan araç değişkenler arasında korelasyon varsa tahminci değerlerinin yorumlanması üzerine kuruludur. Ayrıca, diğer yöntemlerin aksine araç değişken kullanımına yönelik tahmin yöntemi moment koşullarını sağlamayarak hata teriminin birinci fark sonuçlarını etkisiz kılmaktadır. Denklem (4) Anderson ve Hsiao (1982) tarafından oluşturulan yönteme dayanarak oluşturulmaktadır:

$$
\Delta d_{i t}=\alpha \Delta d_{i t-1}+\gamma \Delta y_{i t-1}+\Delta X_{i t-1}^{\prime} \beta+\Delta \mu_{t}+\Delta u_{i t}
$$

Anderson ve Hsiao (1982)'nun yöntemi çerçevesinde birimlere özgü sabit etkiler zaman farkı alınarak ortadan kaldırııır. Sabit etkiler yönteminin istatistiki içeriğinden farklı olarak, Denklem (4) takip edilerek elde edilen regresyon tahminleri tutarlı sonuçlara sahip olmayabilir. Bunun en önemli nedenlerinden biri farkı alınmış araç değişkenler ile hata teriminin kalıntıları arasında ortaya çıkabilecek korelasyondur. Eğer kalıntılar arasında herhangi bir seri korelasyon ${ }^{7}$ yoksa $d_{i t-2}$ ile $\Delta u_{i t}$ arasında mevcut bir korelasyon varlığından bahsetmek mümkün olmayacaktır. Böylece $d_{i t-1} \Delta d_{i t-2}$ için $y_{i t-2}$ ise $\Delta y_{i t-2}$ adına araç değişkenler olarak kullanılabilir.

Bu koşullara bağlı olarak GMM yöntemi, belirtilen tüm diğer iki yönteme göre teknik olarak çok daha etkin bir konumdadır. GMM tahmincileri hata terimi içindeki bireysel etkileri çözümlemede daha sağlam bir altyapıya sahip bulunmaktadır. Arellano ve Bond (1991) GMM yöntemi içerisinde tüm gecikmeli değerlerin araç değişken olarak kullanıımasını önermişlerdir. GMM tahmincisi moment koşullarını tam olarak sağlaması nedeniyle düşük varyans içermektedir. Ayrıca endojenlik sorunlarının mevcut olduğu standart en küçük kareler tahmincilerine göre GMM tahmincisi daha tutarlı, yansız ve etkindir. Ancak Roodman (2006)'ın görüşü bu durumun belli koşullara bağlı olarak gerçekleşebileceği üzerine kuruludur: (i) panel boyutunun geniş olması, (ii) fonksiyonel ilişkilerin doğrusal olması, (iii) bağımlı değişken yapısının dinamik olması ve (iv) birimler arasında değişen varyans ve otokorelasyon olmaması. Arellano ve Bond (1991) tarafından oluşturulan GMM 
yöntemi zaman içerisinde teknik açıdan daha da geliştirilmiş yöntemlere kapı aralamıştır. Örneğin, Arellano ve Bover (1995) bağımlı değişkenin düzey değerlerinde gecikmeli farklarının araç değişken olarak kullanımasını sağlayan sistem-GMM tahmincisini, Blundell ve Bond (1998) ise sistem-GMM tahmincisi için durağanlık kısıtlarını aşmayı sağlayan GMM tahmincisini teknik yönüyle geliştirmiştir.

Ticari küreselleşme ve bölüşüm arasındaki ilişkinin tüm bu yöntemlerin varlığı dahilinde ele alınacağı panel veri analizinde Denklem (5)'e bağlı ekonometrik model spesifikasyonu kullanılacaktır:

$$
\operatorname{LOGGINI}_{i t}=\alpha \operatorname{LOGGINI}_{i t-1}+\gamma L O G T R A D E_{i t-1}+\delta L A B O R_{i t-1}+X_{i t}^{\prime} \beta+\mu_{t}+\sigma_{i}+u_{i t}
$$

OECD ülkelerinin 1980-2016 arası dönem itibarıyla ele alındığı panel veri modellerinde $i$ ülkeleri, $t$ ise zaman boyutunu göstermektedir. Denklem (5)'te LOGGINI değişkeni bölüşüm açısından gelir eşitsizliğini tanımlayan logaritmik ölçekte Gini katsayısını, LOGTRADE göstergesi logaritmik ölçekte ticari küreselleşme ve ticari açıklık değişkenlerini, $L A B O R$ göstergesi emek piyasası ile ilgili değişkenleri ve $X$ ise diğer tüm kontrol değişkenlerini göstermektedir. Denklemde Gini katsayısının gecikmeli değerleri gelir eşitsizliğindeki mevcut sürekliliği ve ortalamaya dönen dinamiği yakalamak için regresyon tahmininde kullanılmak üzere modele dahil edilmiştir. Bu çerçevede, $\gamma$ ve $\delta$ parametreleri sırasıyla ticari küreselleşme/açıklık ve emek piyasası değişkenlerinin gelir eşitsizliği üzerindeki nedensel etkisini ölçmektedir. $\beta$ parametresi ise bu değişkenler dışındaki diğer tüm kontrol değişkenlerinin etkisini yansıtmaktadır. Son olarak, $\mu_{t}$ ve $\sigma_{i}$ ise sırasıyla OECD ülkelerinin gelir eşitsizliği değerleri üzerindeki şokları ve eğilimleri yansıtan gözlemlenemeyen ülkeye özgü etkileri ve gözlemlenemeyen zaman etkilerini göstermektedir.

$\mathrm{Bu}$ nedenle, mevcut faktörlerin modelde yer alması ticari küreselleşme/açıklık düzeyinde yaşanabilecek olası bir hatalı korelasyonun etkilerinden kaçınılmasını sağlamaktadır. Mevcut modelin özelliklerine bağlı kalarak ticari küreselleşme ve ticari açıklık değişkenlerinin bölüşüm üzerindeki etkisinin negatif olması beklenmektedir. Diğer bir ifadeyle, daha liberal bir ticari hesabın analize konu olan ülkeler özelinde gelir eşitsizliğini artırıcı bir etkisinin olduğu varsayılmaktadır.

\section{Temel Analiz Sonuçları}

Tablo 3, Tablo 4 ve Tablo 5 içerisinde yıllık ve 3 yıllık verilerin Denklem (1), Denklem (2) ve Denklem (4)'te belirtilen regresyon analizine bağı sonuçları verilmektedir. Oluşturulan modellerin her biri aynı olmakla birlikte ticari küreselleşme ve ticari açıklık olgularının bölüşüm üzerindeki farklılaşan etkilerini ölçmek için birbirinden bağımsız değişkenler kullanılmıştır. Bu farklıı̆̆ın ardındaki en önemli neden her iki olgunun kendine özgü dinamiklere sahip olmasıdır. Bir diğer belirleyici neden ise her bir olgunun gelir dağılımı üzerinde farklı ancak bir o kadar benzer etkilere sahip olabileceğini göstermesidir. Bu çerçevede Tablo 3, ticari küreselleşme değişkeni olarak KOF Küreselleşme veri tabanından elde edilen endeksi, Tablo 4 ve Tablo 5 ise sırasıyla nominal ve reel ticari açıklık değişkenlerini kullanmaktadır. Sabit Etkiler ve GMM yöntemleri çerçevesinde elde edilen standart hatalar, değişen varyans ve seri korelasyon gibi diagnostik sorunlara tümüyle dirençlidir. Modellerde kullanılan IV ve GMM yöntemleri ise endojenlik sorunlarını da hesaba katarak daha güvenilir ve sağlam test sonuçları elde etmemizi sağlamaktadır.

Tablo 3, Tablo 4 ve Tablo 5 içerisindeki Model 1, Model 2 ve Model 3, sabit etkili panel veri yöntemi ile oluşturulan regresyon tahminleri sonucunda elde edilen katsayıları göstermektedir. Belirtilen her bir modelde, sabit etkilerin regresyona dahil edilmesi sonucunda gelir eşitsizliğini temsil eden Gini katsayısı ile ticari küreselleşme değişkeni arasındaki ilişkinin yüksek oranda anlamlı çıktığı görülmektedir. Bu durum her bir model için istatistiki olarak geçerli bulunmaktadır. Örneğin, Tablo 3'de ticari küreselleşme değişkeni ile ölçülen ticaret değişkeni çerçevesinde $\gamma$ katsayısı gecikmesi alınmamış Model 1 ve 3'te sırasıyla 0,143 ve 0,136 iken, gecikmesi alınmış Model 2'de 0,137'dir. Aynı şekilde standart hatalarında da çok fazla değişim görülmeyen değişken katsayıları \%1 düzeyinde istatistiksel olarak anlamlı çıkmaktadır. Mevcut sonuçlar büyük oranda $\gamma$ katsayısının ticaret açıklığı değişkenleri temelinde elde edildiği Tablo 4 ve Tablo 5'te aynı şekildedir. Sabit etkiler yöntemine bağlı olarak elde edilen tahmin sonuçları çerçevesinde ticaret değişkenleri ile gelir eşitsizliği arasındaki pozitif nedensel ilişkisinin varlığı durumunda mevcut korelasyonun uzun vadeli etkisinin gelir eşitsizliğinin gecikmeli değerlerinin etkisini daha da artıracağı ve zaman içerisinde bu etkinin 
ağırlığının daha fazla olacağı önsel olarak belirtilebilir. Bir anlamda ticaret değişkenlerinin gelir eşitsizliği üzerindeki uzun vadeli kümülatif etkilerinin varlığını hesaba katmak, değişkenler arasındaki nedensel ilişkinin yönünü ve etkisini derinlemesine anlamlandırmamızı sağlayacaktır.

Tablo 3. Temel Regresyon Sonuçları (Ticari Küreselleşme Değişkeni Temelinde)

\begin{tabular}{|c|c|c|c|c|c|c|c|c|}
\hline & \multicolumn{5}{|c|}{ Yıllık Veri } & \multicolumn{3}{|c|}{3 Yıllık Veri } \\
\hline & $\begin{array}{c}\text { Sabit } \\
\text { Etkiler } \\
\text { EKK } \\
\text { Model } 1 \\
\end{array}$ & $\begin{array}{c}\text { Sabit } \\
\text { Etkiler } \\
\text { EKK } \\
\text { Model } 2 \\
\end{array}$ & $\begin{array}{c}\text { Sabit } \\
\text { Etkiler } \\
\text { EKK } \\
\text { Model } 3\end{array}$ & $\begin{array}{c}\text { Anderson- } \\
\text { Hsiao } \\
\text { IV } \\
\text { Model } 4 \\
\end{array}$ & $\begin{array}{l}\text { Arellano- } \\
\text { Bond } \\
\text { GMM } \\
\text { Model } 5 \\
\end{array}$ & $\begin{array}{c}\text { Sabit } \\
\text { Etkiler } \\
\text { EKK } \\
\text { Model } 6\end{array}$ & $\begin{array}{c}\text { Sabit } \\
\text { Etkiler } \\
\text { EKK } \\
\text { Model } 7\end{array}$ & $\begin{array}{l}\text { Arellano- } \\
\text { Bond } \\
\text { GMM } \\
\text { Model } 8\end{array}$ \\
\hline \multicolumn{9}{|c|}{ Bağımlı değişken: loggini } \\
\hline $\operatorname{loggini} i_{t-1}$ & & & & $\begin{array}{c}1,101^{* * *} \\
(0,045)\end{array}$ & $\begin{array}{c}0,767^{* *} \\
(0,389)\end{array}$ & & & $\begin{array}{c}0,097 \\
(0,074)\end{array}$ \\
\hline logtrglob $b_{t-1}$ & & $\begin{array}{c}0,137 * * * \\
(0,011)\end{array}$ & & $\begin{array}{c}0,009 \\
(0,020)\end{array}$ & & & $\begin{array}{c}0,140 * * * \\
(0,011)\end{array}$ & \\
\hline logtrglob & $\begin{array}{c}0,143 * * * \\
(0.009)\end{array}$ & & $\begin{array}{c}0,136 * * * \\
(0,008)\end{array}$ & & $\begin{array}{c}0,142 * * \\
(0,086)\end{array}$ & $\begin{array}{c}0,147 * * * \\
(0,008)\end{array}$ & & $\begin{array}{c}0,135^{* *} \\
(0,062)\end{array}$ \\
\hline crisis & & & $\begin{array}{c}0,015^{* * *} \\
(0,036)\end{array}$ & & & & & \\
\hline Sabit & $\begin{array}{c}2,824 * * * \\
(0,039)\end{array}$ & $\begin{array}{c}2,849 * * * \\
(0,048)\end{array}$ & $\begin{array}{c}2,851 * * * \\
(0,036)\end{array}$ & $\begin{array}{l}-0,000 \\
(0,000)\end{array}$ & & $\begin{array}{c}2,807 * * * \\
(0,039)\end{array}$ & $\begin{array}{c}2,838 * * * \\
(0,048)\end{array}$ & \\
\hline Gözlem sayısı & 999 & 972 & 999 & 918 & 702 & 351 & 351 & 243 \\
\hline Ülke sayısı & 27 & 27 & 27 & 27 & 27 & 27 & 27 & 27 \\
\hline Araç Değişken & & & & & 26 & & & 12 \\
\hline $\mathrm{R}^{2}$ & 0,1403 & 0,1338 & 0,1461 & & & 0,1465 & 0,1354 & \\
\hline Prob $>F$ & 0,0000 & 0,0000 & 0,0000 & 0,0000 & & 0,0000 & 0,0000 & \\
\hline AR (1) & & & & & 0,000 & & & 0,000 \\
\hline$A R(2)$ & & & & & 0,219 & & & 0,568 \\
\hline Hansen J-test & & & & & 0,810 & & & 0,224 \\
\hline Root MSE & & & & 0,0115 & & & & \\
\hline Wald test & & & & & 7,47 & & & 12,68 \\
\hline Prob >chi 2 & & & & & 0,024 & & & 0,002 \\
\hline
\end{tabular}

Not: Model 1, 2, 3, 6 ve 7'deki sabit etkiler yöntemine ait regresyon sonuçları çerçevesinde elde edilen kümelenmiş dirençli standart hatalar parantez içerisindedir ve her bir birim için regresyon tahmininde kukla değişken kullanılmıştır. Model 4'te Anderson ve Hsiao (1982) tarafından oluşturulan araç değişkenler yöntemine bağlı olarak elde edilen tutarlı tahminci katsayı değerlerine bağlı dirençli standart hatalar parantez içerisindedir. Model 5 ve 8'de Arellano ve Bond (1991) tarafından oluşturulan ve Roodman (2006)'ın geliştirdiği GMM yöntemi çerçevesinde elde edilen tutarlı tahminci değerlerine bağlı dirençli standart hatalar parantez içerisindedir. Araç değişken yöntemi içerisinde ticari küreselleşme ve ticari açıklık değişkenleri için iki gecikme değeri araç değişken olarak modele dahil edilirken, GMM yönteminde tek farkı alınmış olarak modele içerilmiştir.

Grafik 3 ve Grafik 4 üzerinden elde edilen betimsel düzeydeki çıkarımlar mevcut ampirik çıktılar tarafından doğrulanmaktadır. OECD ülkelerinin hem ticari küreselleşme ve ticari açıklık hem de gelir eşitsizliği temelindeki farklılıklar göstermektedir ki, belirtilen değişkenler arasında istatistiki düzeyde anlamlı bir nedensel ilişki vardır. Diğer bir ifadeyle, aradaki nedensel ilişkinin analiz edilmesini sağlayan mevcut regresyon tahminlerine göre sabit etkili panel veri yöntemine bağlı ampirik sonuçlar ticari küreselleşme ve ticari açıklık değişkenlerinin gelir eşitsizliğini açıklamada güçlü bir konumda bulunduğunu göstermektedir. Sabit etkili panel veri yönteminin yanı sıra endojenlik sorununu ortadan kaldırmak adına alternatif yöntemler kullanılmakta ve mevcut ilişkinin varlığı bu sorunların çözümü çerçevesinde tekrardan sınanmaktadır. Bağımlı değişkenin gecikmeli değerler olarak dahil edildiği modellerde ortaya çıkabilecek yanlılık sorunlarını ortadan kaldırmak adına bu yeni yöntemler yararlı bir analiz seti sağlayacaktır.

Anderson ve Hsiao (1982)'nun araç değişken yöntemi çerçevesinde elde edilen analiz sonuçları ise Model 4 içerisinde gösterilmektedir. Her ne kadar zaman içerisindeki süreklilik etkisini ölçmek adına açıklayıcı değişken olarak regresyona dahil edilen gelir eşitsizliğinin gecikmeli değeri yüksek oranda anlamlılı̆ı̆ı korusa da ticaret değişkenleri için aynı yorumu yapmak mümkün değildir. Her üç ticaret değişkeni için elde edilen katsayılar pozitif olsa da hiçbir model de anlamlı değildir. Bu sonuçların ardında yatan en önemli teknik neden kullanılan araç değişkenlerin yetersiz olmasıdır. Buna bağlı olarak mevcut değişkenlerin anlamlıl̆ı̆ı sorgulamak ve kesin bir sonuca varmak doğru değildir. Ayrıca katsayıların anlamlı çıkmamasının ardındaki diğer bir neden olarak sadece $d_{i t-2}$ gecikme değerinin kullanılması gösterilebilir. Bu sorunu düzeltmek için 
hata teriminin kalıntıları ile korelasyonlu olmayan tüm $d_{i t}$ araç değişkenlerinin gecikmeli değerleri açıklayıcı değişken olarak regresyona dahil edilebilir. Bu olgu nedenselliğe konu olan değişken arasındaki ilişkiyi kuvvetlendirebilecek ortamı sağlamak için ek bir çözüm yöntemi olarak kullanılabilir.

Tüm bu sorunların varlığı göz önünde bulundurularak Model 5 ve 8'de Arellano ve Bond (1991) tarafından oluşturulan ve Roodman (2006) tarafından geliştirilen fark-GMM yöntemi kullanılmaktadır. Her iki modelde de elde edilen GMM tahmincileri tüm moment koşullarını içerdiği için araç değişken ve sabit etkili panel veri yöntemlerinde mevcut bulunan sorunları çözmeye yönelik alternatif yollara sahiptir. Bu moment koşulları geçerli olduğu zaman GMM yöntemi tarafından elde edilen tahminciler daha tutarlı ve etkin katsayılar üretmektedir. GMM tahmincilerine bağlı olarak elde edilen katsayılar sabit etkili panel veri analizinde elde edilen katsayılara benzer şekilde pozitif ve anlamlıdır. Diğer bir ifadeyle, ticari küreselleşme ve ticari açıklık değişkenleri gelir eşitsizliğini artııı bir etkiye sahiptir. Örneğin, Tablo 3'de ticari küreselleşme değişkenin katsayısı Model 5'te 0,142, Tablo 4 ve Tablo 5'te ise ticari açıklık değişkenlerinin katsayıları sırasıyla 0,112 ve $0,040^{\prime}$ tır.

Tablo 4. Temel Regresyon Sonuçları (Nominal Ticari Açıklık Değişkeni Temelinde)

\begin{tabular}{|c|c|c|c|c|c|c|c|c|}
\hline & \multicolumn{5}{|c|}{ Yıllık Veri } & \multicolumn{3}{|c|}{3 Yıllık Veri } \\
\hline & $\begin{array}{c}\text { Sabit } \\
\text { Etkiler } \\
\text { EKK } \\
\text { Model } 1\end{array}$ & $\begin{array}{c}\text { Sabit } \\
\text { Etkiler } \\
\text { EKK } \\
\text { Model } 2\end{array}$ & $\begin{array}{c}\text { Sabit } \\
\text { Etkiler } \\
\text { EKK } \\
\text { Model } 3\end{array}$ & $\begin{array}{l}\text { Anderson- } \\
\text { Hsiao } \\
\text { IV } \\
\text { Model } 4\end{array}$ & $\begin{array}{l}\text { Arellano- } \\
\text { Bond } \\
\text { GMM } \\
\text { Model } 5\end{array}$ & $\begin{array}{c}\text { Sabit } \\
\text { Etkiler } \\
\text { EKK } \\
\text { Model } 6\end{array}$ & $\begin{array}{c}\text { Sabit } \\
\text { Etkiler } \\
\text { EKK } \\
\text { Model } 7\end{array}$ & $\begin{array}{l}\text { Arellano- } \\
\text { Bond } \\
\text { GMM } \\
\text { Model } 8\end{array}$ \\
\hline \multicolumn{9}{|c|}{ Bağımlı değişken: loggini } \\
\hline $\operatorname{loggini} i_{t-1}$ & & & & $\begin{array}{c}1,049 * * * \\
(0,044)\end{array}$ & $\begin{array}{c}0,552 \\
(0,459)\end{array}$ & & & $\begin{array}{l}0,150^{*} \\
(0,079)\end{array}$ \\
\hline $\operatorname{logtropen}_{t-1}$ & & $\begin{array}{c}0,106 * * * \\
(0,013)\end{array}$ & & $\begin{array}{l}-0,023 \\
(0,023)\end{array}$ & & & $\begin{array}{c}0,109 * * * \\
(0,013)\end{array}$ & \\
\hline logtropen & $\begin{array}{c}0,108^{* * *} \\
(0,012)\end{array}$ & & $\begin{array}{c}0,104^{* * *} \\
(0,013)\end{array}$ & & $\begin{array}{l}0,112^{*} \\
(0,065)\end{array}$ & $\begin{array}{c}0,114 * * * \\
(0.012)\end{array}$ & & $\begin{array}{c}0,097 * * \\
(0,042)\end{array}$ \\
\hline crisis & & & $\begin{array}{l}0,012^{*} \\
(0,006)\end{array}$ & & & & & \\
\hline Sabit & $\begin{array}{c}2,963^{* * *} \\
(0,051)\end{array}$ & $\begin{array}{c}2,977^{* * *} \\
(0,053)\end{array}$ & $\begin{array}{c}2,980 * * * \\
(0,053)\end{array}$ & $\begin{array}{c}0,000 \\
(0,000)\end{array}$ & & $\begin{array}{c}2,941^{* * *} \\
(0,048)\end{array}$ & $\begin{array}{c}2,962 * * * \\
(0,052)\end{array}$ & \\
\hline Gözlem sayısı & 999 & 972 & 999 & 918 & 702 & 351 & 351 & 243 \\
\hline Ülke sayısı & 27 & 27 & 27 & 27 & 27 & 27 & 27 & 27 \\
\hline Araç Değişken & & & & & 26 & & & 12 \\
\hline $\mathrm{R}^{2}$ & 0,1562 & 0,1503 & 0,1601 & & & 0,1691 & 0,1568 & \\
\hline Prob $>F$ & 0,0000 & 0,0000 & 0,0000 & 0,0000 & & 0,0000 & 0,0000 & \\
\hline AR (1) & & & & & 0,009 & & & 0,000 \\
\hline$A R(2)$ & & & & & 0,324 & & & 0,803 \\
\hline Hansen J-test & & & & & 0,690 & & & 0,206 \\
\hline Root MSE & & & & 0,0126 & & & & \\
\hline Wald test & & & & & 9,69 & & & 13,98 \\
\hline Prob $>$ chi2 & & & & & 0,008 & & & 0,001 \\
\hline
\end{tabular}

Not: Model 1, 2, 3, 6 ve 7'deki sabit etkiler yöntemine ait regresyon sonuçları çerçevesinde elde edilen kümelenmiş dirençli standart hatalar parantez içerisindedir ve her bir birim için regresyon tahmininde kukla değişken kullanılmıştır. Model 4'te Anderson ve Hsiao (1982) tarafından oluşturulan araç değişkenler yöntemine bağı olarak elde edilen tutarlı tahminci katsayı değerlerine bağlı dirençli standart hatalar parantez içerisindedir. Model 5 ve 8'de Arellano ve Bond (1991) tarafından oluşturulan ve Roodman (2006)'ın geliştirdiği GMM yöntemi çerçevesinde elde edilen tutarlı tahminci değerlerine bağlı dirençli standart hatalar parantez içerisindedir. Araç değişken yöntemi içerisinde ticari küreselleşme ve ticari açıklık değişkenleri için iki gecikme değeri araç değişken olarak modele dahil edilirken, GMM yönteminde tek farkı alınmış olarak modele içerilmiştir.

GMM yönteminin kullanımının teknik yönden diğer bir avantajı ise çoklu araç değişken kullanılabilmesi dolayısıyla $\Delta u_{i t}$ 'de seri korelasyonun mevcut olup olmamasına yönelik hipotezin sınanabilmesidir. Tüm modellerde ticaret değişkenlerine ait regresyon çıktıları AR(2) testi için seri korelasyon olmadığına dair hipotezin reddedilemeyeceğini göstermektedir. Diğer bir ifadeyle, seriler arası herhangi bir ileri düzeyli seri korelasyon bulunmamaktadır. GMM yöntemine bağlı olarak elde edilen katsayılar Tablo 3 ve Tablo 4'te ticari küreselleşme ve nominal ticaret değişkeni için Tablo 5'te reel ticari açıklık değişkeni temelindeki katsayıya göre daha tutarlı ve etkindir. Bunun en önemli nedeni reel ticaret değişkeninin diğer 
iki değişkene göre fiyat değişimlerini içermesidir. Böylece reel olarak fiyat değişimleri her iki değişkenden arındırılmakta ve seriler daha tutarlı olmaktadır.

Tablo 5. Temel Regresyon Sonuçları (Reel Ticari Açıklık Değişkeni Temelinde)

\begin{tabular}{|c|c|c|c|c|c|c|c|c|}
\hline & \multicolumn{5}{|c|}{ Yıllık Veri } & \multicolumn{3}{|c|}{3 Yıllık Veri } \\
\hline & $\begin{array}{c}\text { Sabit } \\
\text { Etkiler } \\
\text { EKK } \\
\text { Model } 1 \\
\end{array}$ & $\begin{array}{c}\text { Sabit } \\
\text { Etkiler } \\
\text { EKK } \\
\text { Model } 2 \\
\end{array}$ & $\begin{array}{c}\text { Sabit } \\
\text { Etkiler } \\
\text { EKK } \\
\text { Model } 3 \\
\end{array}$ & $\begin{array}{c}\text { Anderson- } \\
\text { Hsiao } \\
\text { IV } \\
\text { Model } 4 \\
\end{array}$ & $\begin{array}{l}\text { Arellano- } \\
\text { Bond } \\
\text { GMM } \\
\text { Model } 5\end{array}$ & $\begin{array}{c}\text { Sabit } \\
\text { Etkiler } \\
\text { EKK } \\
\text { Model } 6\end{array}$ & $\begin{array}{c}\text { Sabit } \\
\text { Etkiler } \\
\text { EKK } \\
\text { Model } 7\end{array}$ & $\begin{array}{l}\text { Arellano- } \\
\text { Bond } \\
\text { GMM } \\
\text { Model } 8 \\
\end{array}$ \\
\hline \multicolumn{9}{|c|}{ Bağımlı değişken: loggini } \\
\hline logginit-1 & & & & $\begin{array}{c}1,083^{* * *} \\
(0,031)\end{array}$ & $\begin{array}{c}0,067 \\
(0,453)\end{array}$ & & & $\begin{array}{c}0,056 \\
(0,071)\end{array}$ \\
\hline logadjtropen $_{t-1}$ & & $\begin{array}{c}0,056^{* * *} \\
(0,002)\end{array}$ & & $\begin{array}{c}0,016 \\
(0,010)\end{array}$ & & & $\begin{array}{c}0,058^{* * *} \\
(0,003)\end{array}$ & \\
\hline logadjtropen & $\begin{array}{c}0,057 * * * \\
(0,002)\end{array}$ & & $\begin{array}{c}0,057 * * * \\
(0,002)\end{array}$ & & $\begin{array}{c}0,040 * * \\
(0,019)\end{array}$ & $\begin{array}{c}0,059 * * \\
(0,003)\end{array}$ & & $\begin{array}{c}0,045^{* * *} \\
(0,016)\end{array}$ \\
\hline crisis & & & $\begin{array}{c}-0,000^{*} \\
(0,004)\end{array}$ & & & & & \\
\hline Sabit & $\begin{array}{c}3,192 * * * \\
(0,011)\end{array}$ & $\begin{array}{c}3,197 * * * \\
(0,010)\end{array}$ & $\begin{array}{c}3,192 * * * \\
(0,011)\end{array}$ & $\begin{array}{c}-0,000^{* *} \\
(0,000)\end{array}$ & & $\begin{array}{c}3,184 * * * \\
(0,014)\end{array}$ & $\begin{array}{c}3,187 * * * \\
(0,012)\end{array}$ & \\
\hline Gözlem sayısı & 999 & 972 & 999 & 918 & 702 & 351 & 351 & 243 \\
\hline Ülke sayısı & 27 & 27 & 27 & 27 & 27 & 27 & 27 & 27 \\
\hline Araç Değişken & & & & & 26 & & & 12 \\
\hline$R^{2}$ & 0,2205 & 0,2245 & 0,2205 & & & 0,2316 & 0,2364 & \\
\hline Prob $>F$ & 0,0000 & 0,0000 & 0,0000 & 0,0000 & & 0,0000 & 0,0000 & \\
\hline AR (1) & & & & & 0,097 & & & 0,000 \\
\hline $\operatorname{AR}(2)$ & & & & & 0,754 & & & 0,705 \\
\hline Hansen J-test & & & & & 0,376 & & & 0,080 \\
\hline Root MSE & & & & 0,0115 & & & & \\
\hline Wald test & & & & & 5,04 & & & 11,34 \\
\hline Prob>chi2 & & & & & 0,080 & & & 0,001 \\
\hline
\end{tabular}

Not: Model 1, 2, 3, 6 ve 7'deki sabit etkiler yöntemine ait regresyon sonuçları çerçevesinde elde edilen kümelenmiş dirençli standart hatalar parantez içerisindedir ve her bir birim için regresyon tahmininde kukla değişken kullanılmıştır. Model 4'te Anderson ve Hsiao (1982) tarafından oluşturulan araç değişkenler yöntemine bağlı olarak elde edilen tutarlı tahminci katsayı değerlerine bağlı dirençli standart hatalar parantez içerisindedir. Model 5 ve 8'de Arellano ve Bond (1991) tarafından oluşturulan ve Roodman (2006)'ın geliştirdiği GMM yöntemi çerçevesinde elde edilen tutarlı tahminci değerlerine bağlı dirençli standart hatalar parantez içerisindedir. Araç değişken yöntemi içerisinde ticari küreselleşme ve ticari açıklık değişkenleri için iki gecikme değeri araç değişken olarak modele dahil edilirken, GMM yönteminde tek farkı alınmış olarak modele içerilmiştir.

Model 1-5 arasındaki katsayılar yıllık veriler ölçeğinde elde edilmiştir. Bu çerçevede, yıllık düzeyde hesaplanan tahminciler gözlem sayısının yüksek olması ve geniş bir zaman boyutunu içermesi dolayısıyla daha sağlam istatistiki bilgiler sağlamaktadır. Yıllık gözlemlere dayalı analizlerin en önemli sorunlarından biri ise gecikmesi alınmış değişkenlerin açıklayıcı değişken olarak regresyona içerildiği durumlarda serilerin gecikme değerlerinin doğru belirlenememesi ve böylece seri korelasyona yola açabilmesidir. Bu çerçevede sabit etkili modellerin ve diğer modellerin tümünde bu olgunun varlığı göz önünde tutularak hem ticari küreselleşme ve ticari açıklık değişkenlerinin hem de gelir eşitsizliği değişkeninin gecikmeli değerleri belirli yan analiz sonuçlarına bağlı olarak hesaplanmıştır. Mevcut sorunun varlığının hesaba katıldığı her modelde ticari küreselleşme ile ticari açıklık ve gelir eşitsizliği arasında pozitif ilişkinin mevcut olduğu görülmektedir.

Model 6-8 arasında ise ticari küreselleşme ile ticari açıklık ve gelir eşitsizliği ilişkisi değişkenlerin üçer yıllık ortalaması üzerinden sabit etkili panel veri yöntemi ve GMM tekniğine bağlı olarak analiz edilmektedir. Elde edilen analiz sonuçları yıllık serilere dayalı bulunan tahminler ile tutarlı olarak mevcut pozitif ilişkiyi doğrulamaktadır. Ayrıca Grafik 3 ve Grafik 4'te belirtilen değişkenler arasındaki pozitif betimsel ilişkiyi istatistiksel olarak olumlamaktadır. Bu sonuçlar çerçevesinde ticari küreselleşmenin ve ticari açıklığın ileri düzeyde sosyo-iktisadi ve toplumsal düzeyde var olması gelir eşitsizliğini artırmakta ve değişkenler arasında uzun vadeli pozitif bir ilişkinin varlığına işaret etmektedir. 
Sonuç olarak, birimlere özgü etkilerin ve endojenlik sorunlarının varlığının mevcut olması durumlarını içeren regresyon tahminlerinin ele alındığı yöntemler çerçevesinde ticari küreselleşme ile ticari açıklık ve gelir eşitsizliği arasında ele alınan modellerde pozitif ve istatistiksel olarak anlamlı sonuçlar elde edildiği görülmektedir. Bu durum ticari küreselleşmenin ve ticari açıklığın gelir dağılımı için olumlu sonuçlar üreteceğini varsayan ana akım görüşlerin tam tersi bir olguyu ortaya çıkarmaktadır. Bu nedenle, farklı sosyoiktisadi ve toplumsal değişkenlerin etkilerini ele alan heterodoks görüşler mevcut sonuçları yorumlamak ve ardında yatan nedenleri anlamak için daha güvenilir konumda bulunmaktadır. Bir sonraki bölümde temel analiz sonuçlarının farklı kontrol değişkenlerinin varlığında geçerliliği sabit etkili panel veri yöntemi ile sınanacaktır. Elde edilecek analiz sonuçları ticari küreselleşme ve ticari açıklık ile gelir eşitsizliği arasındaki pozitif ilişkinin varlığını güçlendirecek faktörleri ortaya çıkarmak adına büyük önem arz etmektedir.

\section{Sağlamlık Testi Sonuçları}

Bu bölümde temel analiz sonuçlarını destekleyici olarak uygulanan sabit etkili panel veri modeli çerçevesinde Driscoll ve Kraay (1998) metoduna bağı regresyon analizi sonuçları açıklanmaktadır. Tablo 6 , Tablo 7 ve Tablo 8 ticari küreselleşme/açıklık ve gelir eşitsizliği arasındaki ilişkinin farklı modeller ölçeğinde geçerliliğinin sınanması üzerine önemli ampirik çıktılar sağlamaktadır. Ticari küreselleşme ve ticari açıkık değişkenlerine ek olarak, aynı spesifikasyonların ihracat ve ithalat düzeyinde de alt açılımları ele alınarak mevcut olgunun farklı yönleri belirtilmektedir. Her ne kadar ticari değişkenlerde yaşanan içerik farklılaşmasına bağlı regresyon tahminlerinde ortaya çıkan değişimler mevcut bulunsa da, gelir eşitsizliği üzerinde ticari küreselleşmenin ve ticari açıklığın etkisi açık bir biçimde görülebilmektedir. Kurulan regresyon tahminlerinin zaman-sabit etkileri içermesi ve modellere dahil edilen açıklayıcı değişkenlerin bazılarının birim kök testlerinde durağan olmayan bir trend içermesi dolayısıyla ek testlerin yapılması sonucu tahmin sonuçlarının daha etkin varsayımları sağladığı belirtilmelidir.

İlk olarak, finansal küreselleşme değişkeni ticari küreselleşme/açıklık değişkenine benzer şekilde gelir eşitsizliğini artırıcı etkide bulunmaktadır. Mevcut tablolara ait tüm regresyonlarda anlamlı ve pozitif sonuçların elde edildiği finansal küreselleşme değişkeninin ticari küreselleşme/açıklık değişkenine benzer özellikler taşıdığı ve gelir eşitsizliği üzerinde önemli bir etki düzeyinin bulunduğu görülmektedir. Bu nedenle, elde edilen ampirik çıktılar ve modellerdeki tahmin sonuçlarının anlamlılık düzeyi, küreselleşme veya iktisadi açıklık olgusunun ele alındığı çalışmalarda hem ticari hem de finansal değişkenlerin bir arada ele alınması gerektiğini önsel olarak belirtmektedir. Küreselleşme ve iktisadi açıklık olgusunun gelir eşitsizliği üzerindeki etkisinin daha dar anlamlara sahip makro temelli temsil (proxy) değişkenleri (örn., (i) finansal küreselleşme endeksi (logfinglob), (ii) devlet harcaması (\% GSYH) (govgdp), (iii) yabancı sermaye yatırımı, dış akış (\%GSYH) (fdiout), (iv) kişi başına GSYH (percapita) ve (v) teknolojik gelişme endeki (tech)) üzerinden ele alınması çerçevesinde farklı sonuçlara ulaşıldığı görülmektedir. Ancak bu değişkenlerin kendine ait özellikleri ve gelir eşitsizliği ile aralarındaki ilişkinin mevcut paradigmanın içeriğini farklılaştırmadığı ve ticari küreselleşme/açıklık ile gelir eşitsizliği arasındaki yüksek anlamlı ve pozitif ilişkiyi koruduğu görülmektedir.

Ticari küreselleşme (logtrglob) ve ticari açıklık (logtropen) değişkenlerinin kullanıldığı regresyonların yanı sıra düzeltilmiş ticari açıklık (logadjtropen) değişkeninin ele alındığı modellerde de gelir eşitsizliği ile aralarındaki pozitif ve yüksek anlamlılık ilişkisi geçerliliğini korumaktadır. Tablo 8'de özetlenen analiz bulguları finansal küreselleşme değişkeninin de aynı anlamlılık düzeyini koruduğunu göstermesi açısından bir önceki sonuçları destekleyici öğeleri içermektedir. Bu nedenle, ticari açıklığın uzun vade de ülkelerin kendi içerisindeki ve böylece küresel düzeydeki gelir eşitsizliği düzeyini düşürücü yöndeki ana akım varsayımlar ile çatışan mevcut sonuçlar karşıt görüşler üzerinde düşünülmeyi gerektirmektedir. Özellikle devlet harcaması artışının gelir eşitliği yönündeki etkisi veya kişi başına GSYH'da meydana gelen artışın gelir eşitsizliğini artıcı yönü ele alınacak karşıt görüşlerin önemli başlıklarını oluşturmaktadır. Örneğin, daha fazla ticari veya finansal küreselleşme mi/açıklık $\mathrm{mı}$ ve daha ileri düzeyde bir devlet harcaması mı gelir eşitliğinin temelini oluşturmaktadır? Veya her iki olgunun bir arada ele alındığı bir iktisadi-politik yapının mı kurulması gereklidir? 
O. Ozdemir - E. Dogan

Tablo 6. Sabit Etkiler Yöntemine Bağlı Regresyon Sonuçları (Ticari Küreselleşme Değişkeni Temelinde)

\begin{tabular}{|c|c|c|c|c|c|c|c|c|c|c|c|}
\hline & Model 1 & Model 2 & Model 3 & Model 4 & Model 5 & Model 6 & Model 7 & Model 8 & Model 9 & Model 10 & Model 11 \\
\hline logtrglob & $\begin{array}{c}0,143^{* * *} \\
(0,009)\end{array}$ & $\begin{array}{c}0,037^{* * *} \\
(0,012)\end{array}$ & & & $\begin{array}{c}0,036^{* * *} * \\
(0,011)\end{array}$ & $\begin{array}{c}0,081^{* * *} \\
(0,018)\end{array}$ & $\begin{array}{c}0,082^{* * *} \\
(0,019)\end{array}$ & $\begin{array}{c}0,082^{* * *} \\
(0,019)\end{array}$ & $\begin{array}{c}0,054^{* *} \\
(0,023)\end{array}$ & & \\
\hline logfinglob & & $\begin{array}{c}0,151^{* * *} \\
(0,019)\end{array}$ & $\begin{array}{c}0,151^{* * *} \\
(0,020)\end{array}$ & $\begin{array}{c}0,152 * * * \\
(0,015)\end{array}$ & $\begin{array}{c}0,150^{* * *} \\
(0,019)\end{array}$ & $\begin{array}{c}0,127^{* * *} \\
(0,017)\end{array}$ & $\begin{array}{c}0,126^{* * *} \\
(0,017)\end{array}$ & $\begin{array}{c}0,125^{* * *} \\
(0,017)\end{array}$ & $\begin{array}{c}0,086 * * * \\
(0,017)\end{array}$ & $\begin{array}{c}0,091^{* * *} \\
(0,018)\end{array}$ & $\begin{array}{c}0,098^{* * *} \\
(0,018)\end{array}$ \\
\hline govgdp & & $\begin{array}{c}-0,005^{* * *} \\
(0,001)\end{array}$ & $\begin{array}{c}-0,005^{* * *} \\
(0,001)\end{array}$ & $\begin{array}{c}-0,006 * * * \\
(0,001)\end{array}$ & $\begin{array}{c}-0,005^{* * *} \\
(0,001)\end{array}$ & $\begin{array}{c}-0,005^{* * *} \\
(0,002)\end{array}$ & $\begin{array}{c}-0,005^{* * *} \\
(0,002)\end{array}$ & $\begin{array}{c}-0,005^{* * *} \\
(0,002)\end{array}$ & $\begin{array}{c}-0,007 * * * \\
(0,001)\end{array}$ & $\begin{array}{c}-0,006^{* * *} \\
(0,001)\end{array}$ & $\begin{array}{c}-0,007 * * * \\
(0,001)\end{array}$ \\
\hline fdiout & & $\begin{array}{c}0,000 \\
(0,000)\end{array}$ & $\begin{array}{c}0,000 \\
(0,000)\end{array}$ & $\begin{array}{c}0,000 \\
(0,000)\end{array}$ & $\begin{array}{c}0,000 \\
(0,000)\end{array}$ & $\begin{array}{c}0,000 \\
(0,000)\end{array}$ & $\begin{array}{c}0,000 \\
(0,000)\end{array}$ & $\begin{array}{c}0,000 \\
(0,000)\end{array}$ & $\begin{array}{c}0,000 \\
(0,000)\end{array}$ & $\begin{array}{l}-0,000 \\
(0,000)\end{array}$ & $\begin{array}{l}-0,000 \\
(0,000)\end{array}$ \\
\hline percapita & & $\begin{array}{c}-0,002^{* *} \\
(0,001)\end{array}$ & $\begin{array}{c}-0,002^{* *} \\
(0,001)\end{array}$ & $\begin{array}{c}-0,002^{* * *} \\
(0,001)\end{array}$ & $\begin{array}{l}-0,001^{*} \\
(0,001)\end{array}$ & $\begin{array}{c}-0,002^{* * *} \\
(0,001)\end{array}$ & $\begin{array}{c}-0,002^{* * *} \\
(0,001)\end{array}$ & $\begin{array}{c}-0,002^{* * *} \\
(0,001)\end{array}$ & $\begin{array}{c}-0,002^{* * *} \\
(0,001)\end{array}$ & $\begin{array}{c}-0,002^{* * *} \\
(0,001)\end{array}$ & $\begin{array}{c}-0,002^{* * *} \\
(0,001)\end{array}$ \\
\hline logexpgdp & & & $\begin{array}{c}0,031 \\
(0,019)\end{array}$ & & & & & & & $\begin{array}{c}0,032^{* *} \\
(0,015)\end{array}$ & \\
\hline logimpgdp & & & & $\begin{array}{c}0,039 * * * \\
(0,014)\end{array}$ & & & & & & & $\begin{array}{c}0,041^{* * *} \\
(0,011)\end{array}$ \\
\hline tech & & & & & & $\begin{array}{c}0,165^{* * *} \\
(0,032)\end{array}$ & $\begin{array}{c}0,166 * * * \\
(0,032)\end{array}$ & $\begin{array}{c}0,166 * * * \\
(0,033)\end{array}$ & $\begin{array}{c}0,137 * * * \\
(0,037)\end{array}$ & $\begin{array}{c}0,145^{* * *} \\
(0,039)\end{array}$ & $\begin{array}{c}0,137^{* * *} \\
(0,036)\end{array}$ \\
\hline logemp & & & & & & $\begin{array}{c}-0,143^{* * *} \\
(0,031)\end{array}$ & $\begin{array}{c}-0,145 * * * \\
(0,031)\end{array}$ & $\begin{array}{c}-0,137 * * * \\
(0,036)\end{array}$ & $\begin{array}{c}-0,237^{* * *} \\
(0,016)\end{array}$ & $\begin{array}{c}-0,203^{* * *} \\
(0,023)\end{array}$ & $\begin{array}{c}-0,221 * * * \\
(0,022)\end{array}$ \\
\hline logavh & & & & & & & $\begin{array}{l}0,009 * * \\
(0,005)\end{array}$ & $\begin{array}{l}0,009^{*} \\
(0,005)\end{array}$ & $\begin{array}{c}0,007 \\
(0,005)\end{array}$ & $\begin{array}{c}0,009 \\
(0,008)\end{array}$ & $\begin{array}{c}0,009 \\
(0,006)\end{array}$ \\
\hline labforce & & & & & & & & $\begin{array}{l}-0,000 \\
(0,000)\end{array}$ & $\begin{array}{l}-0,000 \\
(0,000)\end{array}$ & $\begin{array}{l}-0,000 \\
(0.000)\end{array}$ & $\begin{array}{l}-0,000 \\
(0,000)\end{array}$ \\
\hline humancap & & & & & & & & & $\begin{array}{c}0,100 * * * \\
(0,024)\end{array}$ & $\begin{array}{c}0,092^{* * *} \\
(0,019)\end{array}$ & $\begin{array}{c}0,094 * * * \\
(0,022)\end{array}$ \\
\hline crisis & & & & & $\begin{array}{c}0,002 \\
(0,005)\end{array}$ & $\begin{array}{l}-0,001 \\
(0,007)\end{array}$ & $\begin{array}{c}-0,001 \\
(0,007)\end{array}$ & $\begin{array}{l}-0,001 \\
(0,007)\end{array}$ & $\begin{array}{c}0,001 \\
(0,005)\end{array}$ & $\begin{array}{l}-0,000 \\
(0,005)\end{array}$ & $\begin{array}{l}-0,002 \\
(0,005)\end{array}$ \\
\hline Sabit & $\begin{array}{c}2,824^{* * *} \\
(0,039)\end{array}$ & $\begin{array}{c}2,721^{* * *} \\
(0,050)\end{array}$ & $\begin{array}{c}2,768^{* * *} \\
(0,056)\end{array}$ & $\begin{array}{c}2,748^{* * *} \\
(0,056)\end{array}$ & $\begin{array}{c}2,724^{* * *} \\
(0,056)\end{array}$ & $\begin{array}{c}3,479 * * * \\
(0,195)\end{array}$ & $\begin{array}{c}3,453^{* * *} \\
(0,208)\end{array}$ & $\begin{array}{c}3,417 * * * \\
(0,215)\end{array}$ & $\begin{array}{c}4,152^{* * *} \\
(0,142)\end{array}$ & $\begin{array}{c}4,008^{* * *} \\
(0,169)\end{array}$ & $\begin{array}{c}4,093^{* * *} \\
(0,166)\end{array}$ \\
\hline Gözlem sayısı & 999 & 956 & 956 & 956 & 956 & 956 & 956 & 956 & 956 & 956 & 956 \\
\hline Ülke sayısı & 27 & 27 & 27 & 27 & 27 & 27 & 27 & 27 & 27 & 27 & 27 \\
\hline R2 & 0,1403 & 0,2849 & 0,2882 & 0,2928 & 0,2850 & 0,3279 & 0,3282 & 0,3284 & 0,3581 & 0,3574 & 0,3620 \\
\hline Prob $>F$ & 0,0000 & 0,0000 & 0,0000 & 0,0000 & 0,0000 & 0,0000 & 0,0000 & 0,0000 & 0,0000 & 0,0000 & 0,0000 \\
\hline
\end{tabular}

Not: Standart hatalar parantez içindedir. ${ }^{* * *} p<0,01,{ }^{* *} p<0,05, * p<0,1$.

Bu ve bunun gibi sosyal içeriği geniş soruların ana akım görüşlerin eleştirileri çerçevesinde ele alınması gerektiği belirtilebilir. Bunların yanında bir diğer soru, teknolojinin hangi amaçla kullanıldığı ve toplumsal olgular içerisine nasıl entegre edildiği üzerine kuruludur. Teknolojik gelişme endeksi (tech) temellinde elde edilen katsayılar ileri düzeyde üretime içerilen teknolojinin gelir eşitsizliğini artırıcı etkide bulunduğunu göstermektedir. OECD ülkelerinin gelir düzeyleri ölçeğinde ele alınılması durumunda mevcut çıktının literatürde teknolojinin sermaye-yanlı yapısının olumlandığı bir durumun ortaya çıktığı görülmekte ve örneklem içerisinde bulunan ülkelerin teknolojiyi emek kazançlarını destekleyici nitelikten uzak olduğu varsayımı temelindeki görüşleri desteklediği görülmektedir. Teknolojik gelişme, üretilen ürünlerin birim maliyetlerini düşürerek toplumsal alım-gücünü reel düzeyde yükseltmekte ve yatırımı teşvik ederek emek talebini artırmaktadır. Dolaylı olarak gelir artışlarını da beraberinde getiren bu olgu, emeğin pazarlık gücünü artırarak gelir eşitsizliği artışını yavaşlatıcı ve/veya düşürücü etkide bulunabilir. Ancak mevcut regresyon tahminlerine bağlı bulunarak istihdam artışını desteklemeyen teknolojik gelişmenin OECD ülkelerinde gelir eşitsizliğini artırdığı görülmektedir. Her ne kadar ticari küreselleşme ve ticari açıklık olgusunun ana akım görüşler açısından önemi ekonomik büyüme noktasında temel bir konumda bulunsa da aynı durumun gelir bölüşümü açısından doğruluğu temsil değişkenlerinin de varlığı çerçevesinde sorgulanmayı gerektirmektedir.

Son olarak, ticari küreselleşme ve ticari açıklık ile gelir eşitsizliği arasındaki ilişkinin varlığı belirtilen makro değişkenlerin yanı sıra gelir düzeyini etkileyecek potansiyel faktörlerin de ele alınmasını ve modellere içerilmesini gerektirmektedir. Bu çerçevede, emek piyasası ile ilgili verilerin regresyon tahminlerinde kullanılmasının mevcut ilişkinin içeriği hakkında önemli detaylar sağlayacağı varsayılmaktadır. Emek piyasası verilerinin kullanımasının ardındaki temel amaç, gelir eşitsizliğinde pazarlık gücünün etkilerine odaklanmaktır. Ele alınan modeller içerisinde dört temel değişken emek piyasasında meydana gelen değişimlerin gelir eşitsizliği üzerindeki etkisini anlamak için kullanılmaktadır. Bu değişkenler sırasıyla şu şekildedir: (i) istihdam oranı (logemp), (iii) ortalama çalışma saati (logavh), (ii) işgücüne katılım oranı (labforce) ve (iv) beşeri sermaye endeksi (humancap). ilk olarak, regresyon sonuçlarından istihdam miktarındaki artışın gelir eşitsizliğini azaltıcı yönde etkide bulunduğu görülmektedir. Emek talebi üzerinden değerlendirilebilecek olan bu durum, geleneksel görüşlerle uyum içerisindedir. Emek talebindeki her artış sermaye karşısında emeğin pazarlık gücünü yükseltmesi nedeniyle toplam ulusal gelirdeki eşit dağılımı etkin kılmaktadır. Bu durum, OECD ülkelerindeki gelir grupları arasındaki eşitsizlik farklarının kapanmasına yol açarak toplumsal gelirin dağılımında adil koşulların oluşumunu teşvik etmektedir. Bir diğer önemli değişken 
olarak beşeri sermaye endeksi modellere dahil edilerek gelir eşitsizliği ile arasındaki korelasyon teste tabi tutulmaktadır. Regresyon tahmin sonuçları beşeri sermaye katsayısının pozitif ve istatistiksel olarak anlamlı bulunduğunu göstermektedir. Diğer bir deyişle, sosyo-iktisadi düzeyde bireylerin beşeri sermaye düzeylerinde artışların sermaye karşııındaki pazarlık güçlerini yükseltmeleri paralelinde üretim süreci sonunda üretilen değerden artan pay isteklerini beraberinde getirerek ortalama gelir eşitsizliği düzeyinin azalışını teşvik etmektedir. Ancak belirtilen iki değişkenin yanı sıra regresyon tahminlerinde kullanılan işgücüne katılım oranı ve ortalama çalışma saatleri değişkenleri sırasıyla negatif ve pozitif katsayılara sahip olsa da istatistiksel olarak anlamsız bulunmaktadır.

Tablo 7. Sabit Etkiler Yöntemine Bağıı Regresyon Sonuçları (Nominal Ticari Açıklık Değişkeni Temelinde)

\begin{tabular}{|c|c|c|c|c|c|c|c|c|c|c|c|}
\hline & Model 1 & Model 2 & Model 3 & Model 4 & Model 5 & Model 6 & Model 7 & Model 8 & Model 9 & Model 10 & Model 11 \\
\hline logtropen & $\begin{array}{c}0,109 * * * \\
(0,012)\end{array}$ & $\begin{array}{c}0,040^{* *} \\
(0,017)\end{array}$ & & & $\begin{array}{c}0,040^{* *} \\
(0,018)\end{array}$ & $\begin{array}{c}0,064 * * * \\
(0,014)\end{array}$ & $\begin{array}{c}0,065^{* * *} \\
(0,014)\end{array}$ & $\begin{array}{c}0,065^{* * *} \\
(0,014)\end{array}$ & $\begin{array}{c}0,042^{* * *} \\
(0,013)\end{array}$ & & \\
\hline logfinglob & & $\begin{array}{c}0,148^{* * *} \\
(0,017)\end{array}$ & $\begin{array}{c}0,151^{* * *} \\
(0,020)\end{array}$ & $\begin{array}{c}0,152^{* * *} \\
(0,015)\end{array}$ & $\begin{array}{c}0,148^{* * *} \\
(0,017)\end{array}$ & $\begin{array}{c}0,129 * * * \\
(0,015)\end{array}$ & $\begin{array}{c}0,129 * * * \\
(0,015)\end{array}$ & $\begin{array}{c}0,128^{* * *} \\
(0,015)\end{array}$ & $\begin{array}{c}0,093 * * * \\
(0,018)\end{array}$ & $\begin{array}{c}0,091^{* * *} \\
(0,018)\end{array}$ & $\begin{array}{c}0,098^{* * *} \\
(0,018)\end{array}$ \\
\hline govgdp & & $\begin{array}{c}-0,006^{* * *} \\
(0,001)\end{array}$ & $\begin{array}{c}-0,005^{* * *} \\
(0,001)\end{array}$ & $\begin{array}{c}-0,006^{* * *} \\
(0,001)\end{array}$ & $\begin{array}{c}-0,006^{* * *} \\
(0,001)\end{array}$ & $\begin{array}{c}-0,006^{* * *} \\
(0,001)\end{array}$ & $\begin{array}{c}-0,006 * * * \\
(0,001)\end{array}$ & $\begin{array}{c}-0,006^{* * *} \\
(0,001)\end{array}$ & $\begin{array}{c}-0,007^{* * *} \\
(0,001)\end{array}$ & $\begin{array}{c}-0,006^{* * *} \\
(0,001)\end{array}$ & $\begin{array}{c}-0,007^{* * *} \\
(0,001)\end{array}$ \\
\hline fdiout & & $\begin{array}{c}0,000 \\
(0,000)\end{array}$ & $\begin{array}{c}0,000 \\
(0,000)\end{array}$ & $\begin{array}{c}0,000 \\
(0,000)\end{array}$ & $\begin{array}{c}0,000 \\
(0,000)\end{array}$ & $\begin{array}{c}0,000 \\
(0,000)\end{array}$ & $\begin{array}{c}0,000 \\
(0,000)\end{array}$ & $\begin{array}{c}0,000 \\
(0,000)\end{array}$ & $\begin{array}{l}-0,000 \\
(0,000)\end{array}$ & $\begin{array}{l}-0,000 \\
(0,000)\end{array}$ & $\begin{array}{l}-0,000 \\
(0,000)\end{array}$ \\
\hline percapita & & $\begin{array}{c}-0,002^{* * *} \\
(0,001)\end{array}$ & $\begin{array}{c}-0,002^{* *} \\
(0,001)\end{array}$ & $\begin{array}{c}-0,002^{* * *} \\
(0,001)\end{array}$ & $\begin{array}{c}-0,002^{* *} \\
(0,001)\end{array}$ & $\begin{array}{c}-0,003^{* * *} \\
(0,001)\end{array}$ & $\begin{array}{c}-0,003^{* * *} \\
(0,001)\end{array}$ & $\begin{array}{c}-0,003^{* * *} \\
(0,001)\end{array}$ & $\begin{array}{c}-0,002^{* * *} \\
(0,001)\end{array}$ & $\begin{array}{c}-0,002^{* * *} \\
(0,001)\end{array}$ & $\begin{array}{c}-0,002^{* * *} \\
(0,001)\end{array}$ \\
\hline logexpgdp & & & $\begin{array}{c}0,031 \\
(0,019)\end{array}$ & & & & & & & $\begin{array}{c}0,032^{* *} \\
(0,015)\end{array}$ & \\
\hline logimpgdp & & & & $\begin{array}{c}0,039^{* * *} \\
(0,014)\end{array}$ & & & & & & & $\begin{array}{c}0,041^{* * *} \\
(0,011)\end{array}$ \\
\hline tech & & & & & & $\begin{array}{c}0,173^{* * *} \\
(0,031)\end{array}$ & $\begin{array}{c}0,175^{* * *} \\
(0,031)\end{array}$ & $\begin{array}{c}0,174 * * * \\
(0,031)\end{array}$ & $\begin{array}{c}0,144^{* * *} \\
(0,038)\end{array}$ & $\begin{array}{c}0,145^{* * *} \\
(0,039)\end{array}$ & $\begin{array}{c}0,137^{* * *} \\
(0,036)\end{array}$ \\
\hline logemp & & & & & & $\begin{array}{c}-0,124^{* * *} \\
(0,018)\end{array}$ & $\begin{array}{c}-0,126^{* * *} \\
(0,017)\end{array}$ & $\begin{array}{c}-0,119 * * * \\
(0,021)\end{array}$ & $\begin{array}{c}-0,212^{* * *} \\
(0,022)\end{array}$ & $\begin{array}{c}-0,203^{* * *} \\
(0,023)\end{array}$ & $\begin{array}{c}-0,221 * * * \\
(0,022)\end{array}$ \\
\hline logavh & & & & & & & $\begin{array}{l}0,014^{*} \\
(0,008)\end{array}$ & $\begin{array}{l}0,014^{*} \\
(0,008)\end{array}$ & $\begin{array}{c}0,010 \\
(0,007)\end{array}$ & $\begin{array}{c}0,009 \\
(0,008)\end{array}$ & $\begin{array}{c}0,009 \\
(0,006)\end{array}$ \\
\hline labforce & & & & & & & & $\begin{array}{l}-0,000 \\
(0,000)\end{array}$ & $\begin{array}{l}-0,000 \\
(0,000)\end{array}$ & $\begin{array}{l}-0,000 \\
(0,000)\end{array}$ & $\begin{array}{l}-0,000 \\
(0,000)\end{array}$ \\
\hline humancap & & & & & & & & & $\begin{array}{c}0,090^{* * *} \\
(0,021)\end{array}$ & $\begin{array}{c}0,092 * * * \\
(0,019)\end{array}$ & $\begin{array}{c}0,094 * * * \\
(0,022)\end{array}$ \\
\hline crisis & & & & & $\begin{array}{c}0,001 \\
(0,005)\end{array}$ & $\begin{array}{l}-0,004 \\
(0,006)\end{array}$ & $\begin{array}{c}-0,004 \\
(0,006)\end{array}$ & $\begin{array}{c}-0,004 \\
(0,006)\end{array}$ & $\begin{array}{c}-0,001 \\
(0,005)\end{array}$ & $\begin{array}{l}-0,000 \\
(0,005)\end{array}$ & $\begin{array}{c}-0,002 \\
(0,005)\end{array}$ \\
\hline Sabit & $\begin{array}{c}2,963^{* * *} \\
(0,051)\end{array}$ & $\begin{array}{c}2,729 * * * \\
(0,062)\end{array}$ & $\begin{array}{c}2,768^{* * *} \\
(0,056)\end{array}$ & $\begin{array}{c}2,748^{* * *} * \\
(0,056)\end{array}$ & $\begin{array}{c}2,730 * * * \\
(0,067)\end{array}$ & $\begin{array}{c}3,408^{* * *} * \\
(0,113)\end{array}$ & $\begin{array}{c}3,370 * * * \\
(0,122)\end{array}$ & $\begin{array}{c}3,335^{* * *} \\
(0,128)\end{array}$ & $\begin{array}{c}4,014 * * * \\
(0,175)\end{array}$ & $\begin{array}{c}4,008^{* * *} \\
(0,169)\end{array}$ & $\begin{array}{c}4,093^{* * *} \\
(0,166)\end{array}$ \\
\hline Gözlem sayısı & 999 & 956 & 956 & 956 & 956 & 956 & 956 & 956 & 956 & 956 & 956 \\
\hline Ülke sayısı & 27 & 27 & 27 & 27 & 27 & 27 & 27 & 27 & 27 & 27 & 27 \\
\hline$R^{2}$ & 0,1562 & 0,2919 & 0,2882 & 0,2928 & 0,2919 & 0,3373 & 0,3380 & 0,3381 & 0,3607 & 0,3574 & 0,3620 \\
\hline Prob $>F$ & 0,0000 & 0,0000 & 0,0000 & 0,0000 & 0,0000 & 0,0000 & 0,0000 & 0,0000 & 0,0000 & 0,0000 & 0,0000 \\
\hline
\end{tabular}

Not: Standart hatalar parantez içindedir. ${ }^{* * *} p<0,01,{ }^{* *} p<0,05, * p<0,1$.

Tablo 8. Sabit Etkiler Yöntemine Bağlı Regresyon Sonuçları (Reel Ticari Açıklık Değişkeni Temelinde)

\begin{tabular}{|c|c|c|c|c|c|c|c|c|c|c|c|}
\hline & Model 1 & Model 2 & Model 3 & Model 4 & Model 5 & Model 6 & Model 7 & Model 8 & Model 9 & Model 10 & Model 11 \\
\hline logadjtropen & $\begin{array}{c}0,057^{* * *} \\
(0,002)\end{array}$ & $\begin{array}{c}0,030 * * * \\
(0,005)\end{array}$ & & & $\begin{array}{c}0,031^{* * *} \\
(0,005)\end{array}$ & $\begin{array}{c}0,048^{* * *} \\
(0,008)\end{array}$ & $\begin{array}{c}0,048^{* * *} \\
(0,008)\end{array}$ & $\begin{array}{c}0,049^{* * *} \\
(0,007)\end{array}$ & $\begin{array}{c}0,031^{* * *} \\
(0,011)\end{array}$ & & \\
\hline logfinglob & & $\begin{array}{c}0,118^{* * *} \\
(0,012)\end{array}$ & $\begin{array}{c}0,151^{* * *} \\
(0,020)\end{array}$ & $\begin{array}{c}0,152^{* * *} \\
(0,015)\end{array}$ & $\begin{array}{c}0,117^{* * *} \\
(0,012)\end{array}$ & $\begin{array}{c}0,118^{* * *} \\
(0,016)\end{array}$ & $\begin{array}{c}0,118^{* * *} \\
(0,016)\end{array}$ & $\begin{array}{c}0,115^{* * *} \\
(0,015)\end{array}$ & $\begin{array}{c}0,092^{* * *} \\
(0,013)\end{array}$ & $\begin{array}{c}0,091^{* * *} \\
(0,018)\end{array}$ & $\begin{array}{c}0,098^{* * *} \\
(0,018)\end{array}$ \\
\hline govgdp & & $\begin{array}{c}-0,006^{* * * *} \\
(0,001)\end{array}$ & $\begin{array}{c}-0,005^{* * *} \\
(0,001)\end{array}$ & $\begin{array}{c}-0,006 * * * \\
(0,001)\end{array}$ & $\begin{array}{c}-0,006^{* * *} \\
(0,001)\end{array}$ & $\begin{array}{c}-0,007^{* * *} \\
(0,001)\end{array}$ & $\begin{array}{c}-0,006^{* * *} \\
(0,001)\end{array}$ & $\begin{array}{c}-0,007 * * * \\
(0,001)\end{array}$ & $\begin{array}{c}-0,007 * * * \\
(0,001)\end{array}$ & $\begin{array}{c}-0,006^{* * *} \\
(0,001)\end{array}$ & $\begin{array}{c}-0,007^{* * *} \\
(0,001)\end{array}$ \\
\hline fdiout & & $\begin{array}{c}-0,000 \\
(0,000)\end{array}$ & $\begin{array}{c}0,000 \\
(0,000)\end{array}$ & $\begin{array}{c}0,000 \\
(0,000)\end{array}$ & $\begin{array}{c}0,000 \\
(0,000)\end{array}$ & $\begin{array}{c}0,000 \\
(0,000)\end{array}$ & $\begin{array}{c}0,000 \\
(0,000)\end{array}$ & $\begin{array}{c}0,000 \\
(0,000)\end{array}$ & $\begin{array}{c}0,000 \\
(0,000)\end{array}$ & $\begin{array}{c}-0,000 \\
(0,000)\end{array}$ & $\begin{array}{l}-0,000 \\
(0,000)\end{array}$ \\
\hline percapita & & $\begin{array}{c}-0,001^{* *} \\
(0,001)\end{array}$ & $\begin{array}{c}-0,002^{* *} \\
(0,001)\end{array}$ & $\begin{array}{c}-0,002^{* * *} \\
(0,001)\end{array}$ & $\begin{array}{c}-0,002^{* *} \\
(0,001)\end{array}$ & $\begin{array}{c}-0,002^{* * *} \\
(0,001)\end{array}$ & $\begin{array}{c}-0,002^{* * *} \\
(0,001)\end{array}$ & $\begin{array}{c}-0,002^{* * *} \\
(0,001)\end{array}$ & $\begin{array}{c}-0,002^{* * *} \\
(0,001)\end{array}$ & $\begin{array}{c}-0,002^{* * *} \\
(0,001)\end{array}$ & $\begin{array}{c}-0,002^{* * *} \\
(0,001)\end{array}$ \\
\hline logexpgdp & & & $\begin{array}{c}0,031 \\
(0,019)\end{array}$ & & & & & & & $\begin{array}{c}0,032^{* *} \\
(0,015)\end{array}$ & \\
\hline logimpgdp & & & & $\begin{array}{c}0,039^{* * *} \\
(0,014)\end{array}$ & & & & & & & $\begin{array}{c}0,041^{* * *} \\
(0,011)\end{array}$ \\
\hline tech & & & & & & $\begin{array}{c}0,119 * * * \\
(0,031)\end{array}$ & $\begin{array}{c}0,120^{* * * *} \\
(0,031)\end{array}$ & $\begin{array}{c}0,118^{* * *} \\
(0,031)\end{array}$ & $\begin{array}{c}0,111^{* * *} \\
(0,033)\end{array}$ & $\begin{array}{c}0,145 * * * \\
(0,039)\end{array}$ & $\begin{array}{c}0,137 * * * \\
(0,036)\end{array}$ \\
\hline logemp & & & & & & $\begin{array}{c}-0,209 * * * \\
(0,024)\end{array}$ & $\begin{array}{c}-0,210^{* * *} \\
(0,024)\end{array}$ & $\begin{array}{c}-0,192 * * * \\
(0,028)\end{array}$ & $\begin{array}{c}-0,239 * * * \\
(0,027)\end{array}$ & $\begin{array}{c}-0,203^{* * *} \\
(0,023)\end{array}$ & $\begin{array}{c}-0,221 * * * \\
(0,022)\end{array}$ \\
\hline logavh & & & & & & & $\begin{array}{c}0,009 \\
(0,006)\end{array}$ & $\begin{array}{c}0,009 \\
(0,006)\end{array}$ & $\begin{array}{c}0,007 \\
(0,006)\end{array}$ & $\begin{array}{c}0,009 \\
(0,008)\end{array}$ & $\begin{array}{c}0,009 \\
(0,006)\end{array}$ \\
\hline labforce & & & & & & & & $\begin{array}{l}-0,001 \\
(0,000)\end{array}$ & $\begin{array}{l}-0,000 \\
(0,000)\end{array}$ & $\begin{array}{l}-0,000 \\
(0,000)\end{array}$ & $\begin{array}{l}-0,000 \\
(0,000)\end{array}$ \\
\hline humancap & & & & & & & & & $\begin{array}{c}0,075^{* * *} \\
(0,027)\end{array}$ & $\begin{array}{c}0,092 * * * \\
(0,019)\end{array}$ & $\begin{array}{c}0,094 * * * \\
(0,022)\end{array}$ \\
\hline crisis & & & & & $\begin{array}{c}-0,004 \\
(0,005)\end{array}$ & $\begin{array}{c}-0,008 \\
(0,006)\end{array}$ & $\begin{array}{l}-0,008 \\
(0,006)\end{array}$ & $\begin{array}{l}-0,008 \\
(0,006)\end{array}$ & $\begin{array}{c}-0,004 \\
(0,006)\end{array}$ & $\begin{array}{l}-0,000 \\
(0,005)\end{array}$ & $\begin{array}{c}-0,002 \\
(0,005)\end{array}$ \\
\hline Sabit & $\begin{array}{c}3,192^{* * *} \\
(0,011)\end{array}$ & $\begin{array}{c}2,905^{* * *} \\
(0,050)\end{array}$ & $\begin{array}{c}2,768^{* * *} \\
(0,056)\end{array}$ & $\begin{array}{c}2,748^{* * *} \\
(0,056)\end{array}$ & $\begin{array}{c}2,904 * * * \\
(0,050)\end{array}$ & $\begin{array}{c}4,189 * * * \\
(0,187)\end{array}$ & $\begin{array}{c}4,164^{* * *} \\
(0,186)\end{array}$ & $\begin{array}{c}4,080^{* * *} \\
(0,194)\end{array}$ & $\begin{array}{c}4,362 * * * \\
(0,162)\end{array}$ & $\begin{array}{c}4,008 * * * \\
(0,169)\end{array}$ & $\begin{array}{c}4,093 * * * \\
(0,166)\end{array}$ \\
\hline Gözlem sayısı & 999 & 956 & 956 & 956 & 956 & 956 & 956 & 956 & 956 & 956 & 956 \\
\hline Ülke sayısı & 27 & 27 & 27 & 27 & 27 & 27 & 27 & 27 & 27 & 27 & 27 \\
\hline $\mathrm{R}^{2}$ & 0,2205 & 0,3042 & 0,2882 & 0,2928 & 0,3046 & 0,3482 & 0,3485 & 0,3495 & 0,3626 & 0,3527 & 0,3620 \\
\hline Prob $>F$ & 0,0000 & 0,0000 & 0,0000 & 0,0000 & 0,0000 & 0,0000 & 0,0000 & 0,0000 & 0,0000 & 0,0000 & 0,0000 \\
\hline
\end{tabular}

Not: Standart hatalar parantez içindedir. ${ }^{* * *} p<0,01,{ }^{* *} p<0,05, * p<0,1$. 


\section{Sonuç}

Kapitalist üretim sisteminin tarihsel gelişimi içerisinde gelir eşitsizliği üzerine yapılan çalışmalar çok farklı iktisadi, sosyal ve politik başlıkları ele almıştır. Bu nedenle, mevcut sürece bağlı olarak gelir dağılımı konusu araştırmacıların en temel ilgi alanlarını oluşturmuştur. Ancak, teorik düzlemde yaşanan eksen kaymasının 1980'lerde ortaya çıkması ve buna paralel egemen iktisadi görüş çerçevesinde teşvik edilen daha ileri bir küreselleşme olgusunun gelir dağılımı konusunu ikinci plana atması, iktisadi eşitsizlik düzeyinin zaman içindeki artışııı ardında yatan bileşenleri açıklamaktan ilgili literatürde uzak kalınmasına neden olmuştur. Diğer bir deyişle, mevcut iktisadi görüşler çerçevesinde artan ticari küreselleşme ve ticari açıklık düzeyinin gelir eşitsizliğini hangi yönde etkilediği sorusu günümüzde güncelliğini yitirmiş bir konumda bulunmaktadır. Her ne kadar literatürde gelir eşitsizliğinin her iki ticari değişkene ait olarak olumsuz bir yönde etkilendiğine yönelik heterodoks çalışmalar varlığını korusa da ticaret kanalında uygulanacak daha liberal iktisadi politikaların geliri eşitleyici etkisinin daha ileri bir anlam ifade ettiğini belirten ana akım görüşlerin ağırlığı hissedilmeye devam etmektedir. Böylece, her iki kanada ait olan literatür çalışmaları kendi içlerinde belirtilen iktisadi bağıntının geçerliliğini sınamak adına alternatif görüşlerin varlığını barındırmaktadır. Bu bağlamda, mevcut çalışma gelir eşitsizliğinin hem ticari küreselleşme hem de ticari açıklık ile olan ilişkisini ana akım görüşlerden farklı bir kavramsal yapıda incelemeye çalışmıştır. Yapılan temel analizler ve sağlamlık testleri sonucunda ticari küreselleşmenin ve ticari açıklık olgularının gelir eşitsizliği üzerindeki olumlu yöndeki geleneksel ana akım varsayımların istatistiksel düzeyde geçerli olmadığı ortaya çıkmıştır.

İlk olarak, her bir ticaret değişkeni ile gelir eşitsizliği arasındaki bağıntının pozitif yöndeki varlığı açık bir biçimde mevcut bulunmaktadır. Ticaret alanında yaşanan liberalleşme sürecinin ölçülmesi için kullanılan her üç değişkenin gelir eşitsizliğini artırıcı bir etkiye sahip olduğu istatistiksel olarak anlamlılığını korumaktadır. Her üç değişkenin gelir eşitsizliği üzerindeki etkisi yüksek düzeyde anlamlılığa sahip olarak gelir eşitsizliği ile aralarındaki nedenselliğin varlığını istatistiksel olarak kanıtlamaktadır. Elde edilen bu bulgular farklı iktisadi ve sosyal değişkenlerin kullanıldığı daha ileri düzeyde bir analizi gerektirmektedir. Bu nedenle, ilgili ek değişkenlerin modellere dahil edilmesi sonucunda sabit etkili panel veri analizi çerçevesinde sağlamlık testleri ile mevcut pozitif yönlü ilişkinin varlığı bir kez daha sınanmaktadır.

Her ne kadar mevcut çalışma gelir eşitsizliği ile hem ticari küreselleşme hem de ticari açıklık arasındaki pozitif yönlü ilişkinin varlığını ortaya koysa da sabit etkiler yöntemi altında gelir eşitsizliğini etkileyebilecek potansiyel değişkenleri de modelleme içerisine dahil ederek aralarındaki korelasyonu açığa çıkarmıştır. Buradaki en ilgi çekici sonuç olarak ticari küreselleşme/açıklık değişkenleri kadar finansal küreselleşme değişkeninin de gelir eşitsizliğini olumsuz yönde etkilemesi belirtilebilir. Özellikle toplam iktisadi aktivite çerçevesinde bir bütün halinde değerlendirilmesi gereken küreselleşme olgusunun iki temel ayağını oluşturan ticaret ve finans alanlarının gelir eşitsizliği üzerindeki bu olumsuz etkisi ana akım varsayımların her iki kanaldan da eleştirilmesinin yolunu açması bakımından incelenmeyi gerektirmektedir. Hem finansal liberalizasyonun hem de ticari liberalizasyonun toplam gelirin dağılımı konusunda olumlu çıktılar sağlayacağını belirten geleneksel görüşlerin aksine mevcut modellemelere ait sonuçlar tam tersi olguların geçerli olduğunu göstermektedir.

Araştırmanın kapsamı gelir eşitsizliği ile ticari küreselleşme ve ticari açıklık arasındaki ilişkiyi çok boyutlu olarak inceleme fırsatı sunmaktadır. Bu çerçevede, yukarıda belirtilen açıklayıcı değişkenlere ek olarak emek piyasasında meydana gelen gelişmeler veya makro ölçekli değişimler araştırmaya dahil edilerek geniş tanımlı bir sonuç elde edilmeye çalışılmıştır. Ancak belirtmek gerekir ki hem ticari küreselleşmenin hem de ticari açıklık konusunun iktisadi ve toplumsal boyutu makalede belirtilen sınırları aşmaktadır. Bu nedenle, emek piyasasına yönelik en temel nitelikteki değişkenler regresyon analizine içerilmiş olarak sonuçlar elde edilmiştir. Oluşturulan modellemelerde istihdam oranının ve beşeri sermaye endeksinin gelir eşitsizliği üzerinde istatistiksel olarak anlamlı bir etkisi bulunurken, ortalama çalışma saati ve işgücüne katılım oranı değişkenlerinin etkisi istatistiksel olarak anlamlı çıkmamıştır. Bu sonuçlar istihdamın içeriğine ve yapısına yönelik değişkenlerin ticari küreselleşme ve ticari açıklık olguları kapsamında gelir eşitsizliği ile ilgili olarak daha derin anlamların mevcut olduğuna işaret etmektedir. Sonuç olarak, hem örneklem düzeyinde hem de zamansal açıdan mevcut bağıntının içeriği daha geniş araştırmalara olanak sağlayarak çalışma da belirtilen pozitif yönlü ilişkinin varlığını daha kapsamlı bir çerçevede incelemeye fırsat yaratmaktadır. 


\section{Beyan ve Açıklamalar (Declarations and Disclosures)}

Yazarların Etik Sorumlulukları (Ethical Responsibilities of Authors): Bu çalışmanın yazarları, araştırma ve yayın etiği ilkelerine uyduklarını kabul etmektedirler.

Çıkar Çatışması (Conflicts of Interest): Yazarlar tarafından herhangi bir çıkar çatışması beyan edilmemiştir.

Finansal Destek (Funding): Yazarlar, çalışmanın hazırlanması ve/veya yayınlanması sürecinde herhangi bir finansal destek almamışlardır.

Yazar Katkı Oranı (Author Contributions): Yazarlar, çalışmaya olan katkılarını şu şekilde beyan etmişlerdir: Kavramlaştırma ve çalışma dizaynı, $O$. Özdemir; verilerin toplanması, $E$. Doğan; verilerin analizi ve sonuçların yorumlanması, $O$. Özdemir; çalıșmanın ilk/taslak halinin yazılması, $O$. Özdemir; çalıșmanın gözden geçirilmesi ve düzenlenmesi/düzeltilmesi, E. Doğan. Çalışmanın ilk ve son hali tüm yazarlar tarafından okunmuş ve onaylanmış olup, yazarlar çalışmalarılya ilgili sorumluluğu kabul etmektedirler.

intihal Denetimi (Plagiarism Checking): Bu çalışma, intihal tarama programı kullanılarak intihal taramasından geçirilmiştir.

\section{Son Notlar}

1. OECD ülkeleri için ortalaması alınan Gini katsayısının bu mevcut eğiliminin ülkeler düzeyinde farkılısștığını belirtmek gereklidir. Ancak, ortak eğilimin olumlu yönde seyir izleyen diğer ülkelere sıçrama olasılığı da bir kenara not edilmeli ve zaman içerisinde gelir eşitsizliğinde yaşanan değişimler ve ardında yatan faktörler doğru bir şekilde analiz edilmelidir. Ülke bazında meydana gelen eşitsizlik yanlısı politik argümanlar bölgesel sorunları şiddetlendirebilmesi nedeniyle ayrı çalışmalar altında incelemeye tabi tutulmalıdır.

2. Bununla ilgili verilere Penn World Tables (PWT) 9.1, Conference Board ve AMECO üzerinden ulaşılabilir.

3. Ticaret hacmi ile gelir dağılımı arasındaki bu negatif ilişsi temelindeki ampirik çalışmalar için ayrıca bknz. Milanovic (2005), IMF (2007a, 2007b), Bergh ve Nilsson (2010) ve Pica ve Rodríguez (2011).

4. Tüm bu belirsizlerin varlığının mevcut olduğu belirtilse de Solt (2019) açııından diğer veri tabanlarına göre SWIID veri tabanı büyük oranda üstünlüğü sahiptir. Teorik düzeyde ardında yatan nedenler için bknz. Solt (2009; 2016; 2019).

5. Ticari açıklık ile ilgili farklı ölçüm teknikleri için bknz. Yanikkaya (2003).

6. KOF Globalization veri tabanından elde edilen ticari küreselleşme değişkenine ait teorik içerik için bknz. Dreher (2006).

7. $\Delta u_{i t}$ 'de ikinci dereceden seri korelasyon durumunun olmaması bu duruma örnek oluşturabilir.

\section{Kaynaklar}

Alderson, A., \& Nielsen, F. (2002). Globalization and the great U-turn: Income inequality trends in 16 OECD countries. American Journal of Sociology, 107(5), 1244-1299.

Amiti, M., \& Wei, S. J. (2009). Service offshoring and productivity: Evidence from the US. World Economy, 32(2), 203220.

Anderson, W. T., \& Hsiao, C. (1982). Formulation and estimation of dynamic models using panel data. Journal of Econometrics, 18(1), 47-82.

Arellano, M., \& Bond, R. S. (1991). Some tests of specification for panel data: Monte Carlo evidence and an application to employment equations. Review of Economic Studies, 58(2), 277-297.

Arellano, M., \& Bover, O. (1995). Another look at the instrumental variable estimation of error-components models. Journal of Econometrics, 68(1), 29-51.

Asteriou, D., Dimelis, S., \& Moudatsou, A. (2014). Globalization and income inequality: A panel data econometric approach for the EU27 countries. Economic Modelling, 36, 592-599.

Baltagi, B. (2005). Econometric analysis of panel data. West Sussex: John Wiley \& Sons, Ltd.

Bergh, A., \& Nilsson, T. (2010). Do liberalization and globalization increase income inequality? European Journal of Political Economy, 26(4), 488-505.

Bigsten, A., \& Munshi, F. (2014). Globalisation and inter-occupational inequality: Empirical evidence from OECD countries. The World Economy, 37(3), 501-510. 
Blanchard, O., \& Giavazzi, F. (2003). Macroeconomic effects of regulation and deregulation in goods and labor markets. Quarterly Journal of Economics, 118(3), 879-907.

Blundell, R., \& Bond, S. (1998). Initial conditions and moment restrictions in dynamic panel data models. Journal of Econometrics, 87(1), 115-143.

Brady, D., \& Wallace, M. (2000). Spatialization, foreign direct investment and labor outcomes in the American States, 1978-1996. Social Forces, 79(1), 67-99.

Dabla-Norris, E., Kochhar, K., Suphaphiphat, N., Ricka F., \& Tsounta, E. (2015). Causes and consequences of income inequality: A global perspective. International Monetary Fund, IMF Staff Discussion Notes, 15/13.

Dao, M. C., Das, M., Koczan, Z., \& Lian, W. (2017). Why is labor receiving a smaller share of global income? Theory and empirical evidence. International Monetary Fund, IMF Working Paper WP/17/169.

Decreuse, B., \& Maarek, P. (2015). FDI and the labor share in developing countries: A theory and some evidence. Annals of Economics and Statistics, 119/120, 289-319.

Doan, H. T. T., \& Wan, G. (2017). Globalization and the labor share in national income. ADBI Working Paper No. 639, Asian Development Bank Institute.

Dreher, A. (2006). Does globalization affect growth? Evidence from a new index of globalization. Applied Economics, 38(10), 1091-1110.

Driscoll, C. J., \& Kraay, C. A. (1998). Consistent covariance matrix estimation with spatially dependent panel data. Review of Economics and Statistics, 80(4), 549-560.

Dünhaupt, P. (2017). Determinants of labour's income share in the era of financialisation. Cambridge Journal of Economics, 41(1), 283-306.

European Commission (2007). Employment in Europe. Brussels.

Feenstra, R., \& Hanson, G. H. (1996). Globalization, outsourcing, and wage inequality. American Economic Review, 86(2), 240-245.

Giovannoni, O. (2014). What do we know about the labor share and the profit share? Part II: Empirical studies. Levy Economics Institute, Economics Working Paper Archive No. 805.

Goldberg, P. K., \& Pavcnik, N. (2007). Distributional effects of globalization in developing countries. Journal of Economic Literature, 45(1), 39-82.

Gourdon, J., Maystre, N., \& de Melo, J. (2008). Openness, inequality and poverty: Endowments matter. The Journal of International Trade \& Economic Development, 17(3), 343-378.

Greene, H. W. (2003). Econometric analysis. Upper Saddle River, New Jersey: Prentice Hall.

Grossman, G. M., \& Rossi-Hansberg, E. (2008). Trading tasks: A simple theory of offshoring. American Economic Review, 98(5), 1978-1997.

Guscina, A. (2006). Effects of globalization on labor's share in national income. International Monetary Fund, IMF Working Paper WP/06/294.

Harrison, A. (2005). Has globalization eroded labor's share? Some cross-country evidence. Munich Personal RePEc Archive, MPRA Paper No: 39649, April.

Hummels, D., Jorgensen, R., Munch, J., \& Xiang, C. (2014). The wage and employment effects of outsourcing: Evidence from Danish matched worker-firm data. American Economic Review, 104(6), 1597-1629.

IMF (International Monetary Fund) (2007a). The globalization of labor. In World Economic Outlook, April 2007, Washington, DC.

IMF (International Monetary Fund) (2007b). Globalization and inequality. In World Economic Outlook, October 2007, Washington, DC.

Jaumotte, F., \& Tytell, I. (2007). How has the globalization of labor income affected the labor income share in advanced countries? International Monetary Fund, IMF Working Paper WP/07/298.

Koopman, R., Wang, Z., \& Wei, S. J. (2014). Tracing value-added and double counting in gross exports. American Economic Review, 104(2), 459-494.

Kraay, A. (2006). When is growth pro-poor? Evidence from a panel of countries. Journal of Development Economics, 80(1), 198-227.

Kristal, T. (2010). Good times, bad times: Postwar labor's share of national income in capitalist democracies. American Sociological Review, 75(5), 729-763. 
Meschi, E., \& Vivarelli, M. (2009). Trade and income inequality in developing countries. World Development, 37(2), 287302.

Milanovic, B. (2005). Can we discern the effect of globalization on income distribution? Evidence from household surveys. World Bank Economic Review, 19(1), 21-44.

Pica, G., \& Rodriguez, M. J. V. (2011). Who's afraid of a globalized world? Foreign direct investments, local knowledge and allocation of talents. Journal of International Economics, 85(1), 86-101.

Piketty, T. (2014). Capital in the twenty-first century. Cambridge, Massachusetts: Harvard University Press.

Rodrik, D. (1997). Capital mobility and labor. Draft paper prepared for the NBER workshop on Trade, Technology, Education, and the U.S. Labor Market, Harvard University, April 30-May 1, 1998.

Roine, J., Vlachos J., \& Waldenström, D. (2009). The long-run determinants of inequality: What can we learn from top income data? Journal of Public Economics, 93(7-8), 974-988.

Roodman, D. (2006). How to do xtabond2: An introduction to "difference" and "system" GMM in Stata. Center for Global Development, Working Paper Number 103, December.

Sebastian, E. (1997). Trade policy, growth, and income distribution. American Economic Review, 87(2), $205-210$.

Solt, F. (2009). Standardizing the world income inequality database. Social Science Quarterly, 90(2), 231-242.

Solt, F. (2016). The standardized world income inequality database. Social Science Quarterly, 97(5), 1267-1281.

Solt, F. (2019). Measuring income inequality across countries and over time: The standardized world income inequality database. SWIID version 8.1, May.

Stockhammer, E. (2009). Determinants of functional income distribution in OECD countries. IMK Studies 05-2009, IMK at the Hans Boeckler Foundation, Macroeconomic Policy Institute.

Stockhammer, E. (2013). Why have wage shares fallen? A panel of the determinants of functional income distribution. Conditions of Work and Employment, 35, Geneva: International Labor Organization.

Tatoğlu, Y. F. (2016). Panel veri ekonometrisi: Stata uygulamalı. Ankara: Beta Basım Yayım.

Wood, A. (1995). How trade hurt unskilled workers. The Journal of Economic Perspectives, 9(3), 57-80.

Yanikkaya, H. (2003). Trade openness and economic growth: A cross-country empirical investigation. Journal of Development Economics, 72(1), 57-89.

Yay, G., Taştan, H., \& Oktayer, A. (2016). Globalization, economic freedom, and wage inequality: A panel data analysis. Panoeconomicus, 63(5), 581-601.

Young, A. T., \& Tackett, M. Y. (2018). Globalization and the decline in labor shares: Exploring the relationship beyond trade and financial flows. European Journal of Political Economy, 52, 18-35. 